Historic, Archive Document

Do not assume content reflects current scientific knowledge, policies, or practices. 



\section{Spring 1920 Price List}

\section{GENERAL INDEX}

Terms and Conditions . $\quad . \quad$. $\quad$. 2

Evergreen Trees . . . . . 3

Evergreen Shrubs . . . . . $\quad 12$

Rhododendrons . $\quad$. $\quad$. $\quad 14$

Deciduous Trees . . . . . 16

Deciduous Shrubs . . . . 24

Vines and Climbers . . $\quad 39$

Roses . . . . . . 41

Fruit Trees. . . 43

Small Fruits . . . . . 44

Index to Botanical Names . . . 45

Index to Common Names . . . 46

Our Location . . . . . . 48

Long Distance Telephone, Framingham 331.

Telegraphic Address, Framingham, Mass.

Cable Address, Fram. Boston. 


\section{THE PLANTING SEASON}

The Spring planting season begins as soon as the frost is out of the ground which is generally about the first of April, and continues until early in June.

\section{SHIPPING DIRECTIONS}

Parties ordering are requested to state explicitly the mode of conveyance by which they desire their stock forwarded. When no route is designated, we exercise our judgment; but in no case do we assume any responsibility after packages are shipped, unless for our own mistakes. When losses occur by detention, claims should at once be made on the transportation company.

Certificate of Inspection Accompanies every Shipment.

\section{CONDITIONS OF SALE}

1. The articles on the following list will be furnished at the annexed prices only when the quantity specified shall be taken. FIFTY of the same variety and size will be furnished at the hundred rate; and FIVE at the ten rate. The prices stated are for stock of our selection. Purchasers desiring to select specimen stock must expect to pay higher prices.

2. We give no warranty, expressed or implied, as to quality, description, productiveness, or any other matter of any nursery stock that we sell. No complaints as to shortages, quality of stock, or faulty packing will be considered unless made within five days after receipt of stock.

3. The prices annexed are for the stock F. O. B. our nurseries. They do not include the packing boxes or bales. We charge for the actual cost of the boxes or the material used in baling except on orders paid in full in advance. We make no charge for the delivery of shipments to the freight or express stations.

4. This price list cancels all previous lists. We reserve the right to change the annexed prices at any time without notice.

5. Our terms are net cash, unless by special arrangement. We will ship by Express C. O. D. when desired, with charges for collection added to the bill - provided 50 per cent of the amount of the order accompanies the order as a guarantee. All charge accounts thirty days overdue will accrue interest at the rate of six per cent per year beginning with the thirty-first day.

\section{FRAMINGHAM NURSERIES}




\section{HARDY EVERGREEN TREES}

We always Ball and Burlap our evergreens at No Additional Cost.

Each Per 10 Per 100

ABIES arizonica

4 to $5 \mathrm{ft} . \ldots \ldots \ldots \ldots \ldots \ldots \ldots \ldots$......... 800

arizonica glauca

6 to $7 \mathrm{ft} . \ldots \ldots \ldots \ldots \ldots \ldots \ldots 2000$

balsamea

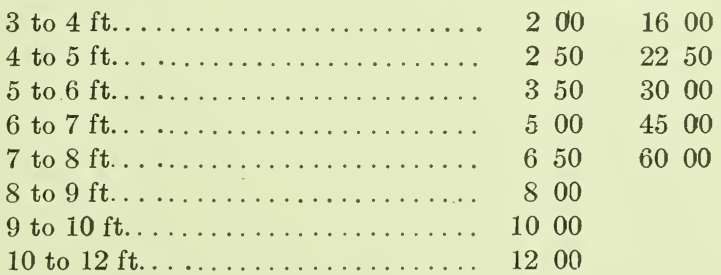

bal. hudsonica glauca

12 to 15 in.................. 500

brachyphylla

$21 / 2$ to $3 \mathrm{ft} . \ldots \ldots \ldots \ldots \ldots \ldots \ldots$. 400

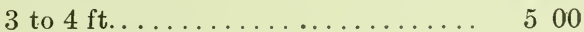

4 to $5 \mathrm{ft} . \ldots \ldots \ldots \ldots \ldots \ldots \ldots \ldots, 700$

concolor

$2 \mathrm{ft} . \ldots \ldots \ldots \ldots \ldots \ldots \ldots \ldots \ldots \ldots$. $300 \quad 2750 \quad 25000$

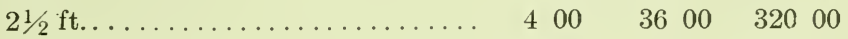

$3 \mathrm{ft} . \ldots \ldots \ldots \ldots \ldots \ldots \ldots \ldots \ldots . \ldots 200 \quad 4500 \quad 40000$

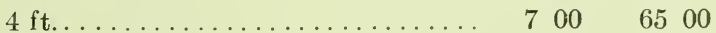

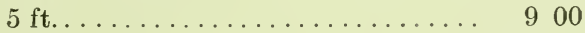

$6 \mathrm{ft} \ldots \ldots \ldots \ldots \ldots \ldots \ldots \ldots \ldots \ldots$

$7 \mathrm{ft} . \ldots \ldots \ldots \ldots \ldots \ldots \ldots \ldots \ldots \ldots$

$8 \mathrm{ft} \ldots \ldots \ldots \ldots \ldots \ldots \ldots \ldots \ldots \ldots$

9 to $15 \mathrm{ft} \ldots \ldots \ldots \ldots 2000$ to 5000

frazeri

3 to $4 \mathrm{ft} . \ldots \ldots \ldots \ldots \ldots \ldots \ldots \ldots . \ldots \ldots$

4 to $5 \mathrm{ft} \ldots \ldots \ldots \ldots \ldots \ldots \ldots \ldots \ldots . \ldots \ldots$

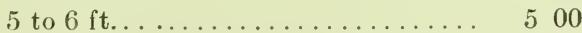

6 to $7 \mathrm{ft} \ldots \ldots \ldots \ldots \ldots \ldots \ldots \ldots$

7 to $8 \mathrm{ft} . \ldots \ldots \ldots \ldots \ldots \ldots \ldots \ldots$. 800

8 to $9 \mathrm{ft} . \ldots \ldots \ldots \ldots \ldots \ldots \ldots \ldots \ldots 1000$

9 to $10 \mathrm{ft} \ldots \ldots \ldots \ldots \ldots \ldots \ldots$

frazeri prostrata

Duarf Frazer Fir

A New and Distinctive Dwarf Plant suitable for Partially Shaded Spots

2 to $21 / 2 \mathrm{ft}$. spread....................... 1000

$21 / 2$ to $3 \mathrm{ft}$. spread........... 1500 
ABIES-continued

veitchii

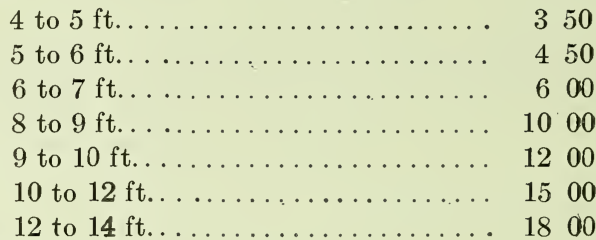

JUNIPERUS chinensis

3 to $4 \mathrm{ft} . \ldots \ldots \ldots \ldots \ldots \ldots$

4 to $5 \mathrm{ft} . \ldots \ldots \ldots \ldots \ldots \ldots \ldots \ldots$

5 to $6 \mathrm{ft} . \ldots \ldots \ldots \ldots \ldots \ldots \ldots$

6 to $7 \mathrm{ft} . \ldots \ldots \ldots \ldots \ldots \ldots \ldots$

7 to $8 \mathrm{ft}$.

chin. argentea

3 to $4 \mathrm{ft} . \ldots \ldots \ldots \ldots \ldots \ldots \ldots$

4 to $5 \mathrm{ft} . \ldots \ldots \ldots \ldots \ldots \ldots \ldots$

5 to $6 \mathrm{ft} . \ldots \ldots \ldots \ldots \ldots \ldots \ldots \ldots$

6 to $7 \mathrm{ft} \ldots \ldots \ldots \ldots \ldots \ldots \ldots \ldots$

chin pfitzeriana

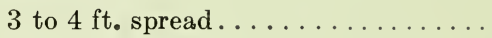

4 to $5 \mathrm{ft}$. spread

5 to $6 \mathrm{ft}$. spread.

chin. procumbens

15 to 18 in. spread communis depressa

15 to 18 in. spread

18 to 24 in. spread

2 to $21 / 2 \mathrm{ft}$. spread

$21 / 2$ to $3 \mathrm{ft}$. spread

3 to $4 \mathrm{ft}$. spread.

4 to $5 \mathrm{ft}$. spread

com. dep. aurea

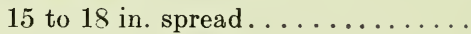

18 to 24 in. spread. com. cracovica

2 to $21 / 2 \mathrm{ft}$. .

$21 / 2$ to $3 \mathrm{ft}$.

3 to $4 \mathrm{ft}$.

4 to $5 \mathrm{ft}$.

com. hibernica

2 to $21 / 2 \mathrm{ft}$

$21 / 2$ to $3 \mathrm{ft}$.

3 to $4 \mathrm{ft}$.

4 to $5 \mathrm{ft}$.

5 to $6 \mathrm{ft}$.
Each Per 10 Per 100 Japanese Fir

\section{Chinese Juniper}

$350 \quad 3200$

$500 \quad 4500$

$\begin{array}{llll}7 & 00 & 60 & 00\end{array}$

$\begin{array}{llll}10 & 00 \quad 90 & 00\end{array}$

1200

Silvery Chinese Juniper 600

800

600

1000

1500

Spreading Chinese Juniper $250 \quad 2200$

Common Spreading Juniper

$\begin{array}{lllll}125 & 1000 & 9000\end{array}$

$\begin{array}{llllll}1 & 50 & 13 & 50 & 120 & 00\end{array}$

$\begin{array}{llllll}200 & 18 & 00 & 160 & 00\end{array}$

$\begin{array}{llllll}300 & 26 & 00 & 240 & 00\end{array}$

$\begin{array}{llllll}500 & 4500 & 400 & 00\end{array}$

$800 \quad 7000$

Golden Common Juniper 200

300

\section{Polish Juniper}

$200 \quad 1800$

250

$\begin{array}{llll}300 & 28 & 00\end{array}$

$\begin{array}{llll}400 & 36 & 00\end{array}$

Irish Juniper

$\begin{array}{rrrrrrr}1 & 00 & 9 & 00 & 80 & 00 \\ 1 & 50 & 12 & 50 & 100 & 00 \\ 2 & 00 & 18 & 00 & & \\ 3 & 50 & 30 & 00 & 260 & 00 \\ 5 & 00 & 45 & 00 & & \end{array}$


JUNIPERUS - continued

com. oblonga

5 to $6 \mathrm{ft}$

com. suecica

18 to 24 in.................... .

2 to $21 / 2 \mathrm{ft} . \ldots \ldots \ldots \ldots \ldots \ldots \ldots$

$21 / 2$ to $3 \mathrm{ft} . \ldots \ldots \ldots \ldots \ldots \ldots$ excelsa stricta

2 to $21 / 2 \mathrm{ft} . \ldots \ldots \ldots \ldots \ldots \ldots$

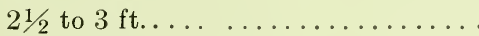

3 to $4 \mathrm{ft} . \ldots \ldots \ldots \ldots \ldots \ldots \ldots$

4 to $5 \mathrm{ft} . \ldots \ldots \ldots \ldots \ldots \ldots$ japonica

5 to $6 \mathrm{ft} \ldots \ldots \ldots \ldots \ldots \ldots \ldots \ldots$

2 to $21 / 2 \mathrm{ft}$.

$21 / 2$ to $3 \mathrm{ft}$

jap. aurea

18 to 24 in

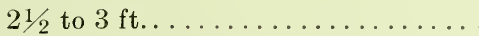

3 to $4 \mathrm{ft}$. .

macrocarpa (neaboriensis)

$2 \frac{1}{2}$ to $3 \mathrm{ft} \ldots \ldots \ldots \ldots \ldots \ldots$

3 to $4 \mathrm{ft} . \ldots \ldots \ldots \ldots \ldots \ldots \ldots$

sabina

18 to 24 in. spread.............

2 to $2 \frac{1}{2} \mathrm{ft}$. spread............

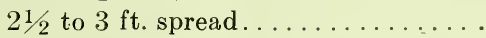

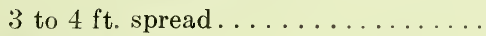

4 to $5 \mathrm{ft}$. spread

virginalis globosa

9 to 12 in. spread.

18 to 24 in. spread virginiana

3 to $4 \mathrm{ft} . \ldots \ldots \ldots \ldots \ldots \ldots . \ldots . \ldots$

4 to $5 \mathrm{ft} . \ldots \ldots \ldots \ldots \ldots \ldots \ldots$

5 to $6 \mathrm{ft} . \ldots \ldots \ldots \ldots \ldots \ldots \ldots$

6 to $7 \mathrm{ft} \ldots \ldots \ldots \ldots \ldots \ldots \ldots$

7 to $8 \mathrm{ft} \ldots \ldots \ldots \ldots \ldots \ldots \ldots$

8 to $9 \mathrm{ft} . \ldots \ldots \ldots \ldots \ldots \ldots \ldots$

9 to $10 \mathrm{ft} . \ldots \ldots \ldots \ldots \ldots \ldots \ldots$

10 to $12 \mathrm{ft}$

virg. elegantissima

3 to $4 \mathrm{ft}$.

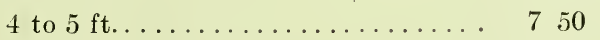

5 to $6 \mathrm{ft} . \ldots \ldots \ldots \ldots \ldots \ldots \ldots \ldots . \ldots 100 \ldots$

6 to $7 \mathrm{ft} \ldots \ldots \ldots \ldots \ldots \ldots \ldots \ldots$

7 to $8 \mathrm{ft} . \ldots \ldots \ldots \ldots \ldots \ldots \ldots \ldots$
Each Per 10 Per 100

Caucasian Juniper

1000

Swedish Juniper

$\begin{array}{lllll}75 & 650 & 5500\end{array}$

$\begin{array}{llllll}1 & 00 & 9 & 00 & 80 & 00\end{array}$

$150 \quad 1250 \quad 100 \quad 00$

Greek Juniper

300

400

$\begin{array}{llllll}5 & 00 & 45 & 00 & 400 & 00\end{array}$

$800.7500 \quad 65000$

$1200 \quad 10000$

Japanese Juniper

$\begin{array}{llll}300 & 28 & 00\end{array}$

$400 \quad 3800$

Golden Japanese Juniper 200

300

500

300

Large-fruiled Juniper

400

500

Sabin Juniper

$\begin{array}{llllll}2 & 00 & 18 & 00 & 16000\end{array}$

$250 \quad 2250 \quad 20000$

$\begin{array}{llllll}350 & 32 & 00 & 300 & 00\end{array}$

$\begin{array}{llllll}5 & 00 & 4500 & 40000\end{array}$

800

Japanese Globe Juniper

250

500

Red or Virginia Cedar

$\begin{array}{llllll}250 & 2250 & 200 & 00\end{array}$

$400 \quad 3600 \quad 32000$

$600 \quad 5500$

$\begin{array}{llll}8 & 00 & 75 & 00\end{array}$

$\begin{array}{llll}10 & 00 & 9500\end{array}$

$\begin{array}{llll}15 & 00 & 140 & 00\end{array}$

$\begin{array}{llll}20 & 00 & 190 & 00\end{array}$

$2500 \quad 24000$

Golden Virginia Cedar

500

50 
JUNIPERUS-continued

virg. glauca

\begin{tabular}{|c|c|}
\hline to $4 \mathrm{ft}$. & 400 \\
\hline 4 to $5 \mathrm{ft}$. & 500 \\
\hline $6 \mathrm{ft} . \ldots$ & 750 \\
\hline & 10 \\
\hline ft. . & 15 \\
\hline ft. . & 20 \\
\hline $\mathrm{ft}$. & 25 \\
\hline
\end{tabular}

PICEA alba

3 to $4 \mathrm{ft}$.

4 to $5 \mathrm{ft}$.

5 to $6 \mathrm{ft}$.

6 to $7 \mathrm{ft}$

7 to $8 \mathrm{ft}$.

8 to $9 \mathrm{ft}$.

9 to $10 \mathrm{ft}$.

10 to $12 \mathrm{ft}$

12 to $14 \mathrm{ft}$.

engelmanni

6 to $7 \mathrm{ft}$. specimens

7 to $8 \mathrm{ft}$. specimens

8 to $9 \mathrm{ft}$. specimens

9 to $10 \mathrm{ft}$. specimens

10 to $12 \mathrm{ft}$. specimens

12 to $18 \mathrm{ft}$. specimens excelsa

3 to $4 \mathrm{ft}$

4 to $5 \mathrm{ft}$.

7 to $8 \mathrm{ft}$.

8 to $10 \mathrm{ft}$.

10 to $12 \mathrm{ft}$.

12 to $14 \mathrm{ft}$.

nigra

2 to $3 \mathrm{ft}$.

omorica

5 to $6 \mathrm{ft}$.

pungens

2 to $3 \mathrm{ft}$.

3 to $4 \mathrm{ft}$. specimens

4 to $5 \mathrm{ft}$ specimens

5 to $6 \mathrm{ft}$. specimens

6 to $7 \mathrm{ft}$. specimens

7 to $8 \mathrm{ft}$ specimens

8 to $15 \mathrm{ft}$. specimens
Each Per 10 Per 100 Blue Cedar

400

500

500

2500

White Spruce

$\begin{array}{llll}160 & 14 & 00\end{array}$

12000

$\begin{array}{llllll}2 & 00 & 18 & 00 & 160 & 00\end{array}$

300

400

600

$800 \quad 7500$

$\begin{array}{llll}10 & 00 & 9500\end{array}$

$\begin{array}{llll}12 & 00 & 110 & 00\end{array}$

$1500 \quad 140 \quad 00$

2000

Engelman's Spruce

$\begin{array}{llll}10 & 00 & 95 & 00\end{array}$

$1200 \quad 11000$

$\begin{array}{llll}15 & 00 & 140 & 00\end{array}$

$\begin{array}{llll}18 & 00 & 170 & 00\end{array}$

$2500 \quad 240 \quad 00$

3000 to 5000

Norway Spruce

$150 \quad 1250 \quad 100.00$

$250 \quad 2250 \quad 200 \quad 00$

$\begin{array}{llll}6 & 00 & 5500\end{array}$

$\begin{array}{llll}700 & 6500\end{array}$

$\begin{array}{llll}10 & 00 & 90 & 00\end{array}$

1200

\section{Black Spruce}

$150 \quad 1250$

\section{Serbian Spruce}

1000

Colorado Green Spruce

$\begin{array}{llllll}300 & 2800 & 250 & 00\end{array}$

$\begin{array}{llll}4 & 00 & 36 & 00\end{array}$

600

$\begin{array}{llll}8 & 00 & 7500\end{array}$

$\begin{array}{llll}10 & 00 \quad 90 & 00\end{array}$

$1200 \quad 11000$ 
PICEA-continued

pung. glauca

2 to $3 \mathrm{ft} . \ldots \ldots \ldots \ldots \ldots \ldots$

Each Per 10 Per 100

3 to $4 \mathrm{ft}$. specimens.............

Colorado Blue Spruce

4 to $5 \mathrm{ft}$. specimens

$\begin{array}{llllll}4 & 00 & 36 & 00 & 320 & 00\end{array}$

5 to $6 \mathrm{ft}$. specimens.......... $1000 \quad 9500$

6 to $7 \mathrm{ft}$. specimens........... $1200 \quad 11000 \quad 100000$

7 to $8 \mathrm{ft}$. specimens. . .......... $1500 \quad 140 \quad 00 \quad 130000$

8 to $9 \mathrm{ft}$. specimens............ $2000 \quad 19000$

9 to $10 \mathrm{ft}$. specimens........... $2500 \quad 24000$

10 to $16 \mathrm{ft}$. specimens.......30 00 to 5000

pung. kosteriana

6 to $7 \mathrm{ft}$. specimens

7 to $8 \mathrm{ft}$. specimens

8 to $9 \mathrm{ft}$. specimens

9 to $12 \mathrm{ft}$. specimens
Koster Blue Spruce

$\begin{array}{llll}14 & 00 & 130 & 00\end{array}$

$\begin{array}{llll}18 & 00 & 170 & 00\end{array}$

$2500 \quad 24000$
PINUS austriaca

$21 / 2$ to $3 \mathrm{ft}$.

3 to $4 \mathrm{ft}$. specimens

4 to $5 \mathrm{ft}$. specimens.

5 to $6 \mathrm{ft}$. specimens

6 to $7 \mathrm{ft}$. specimens

7 to $8 \mathrm{ft}$. specimens

\section{divaricata or banksiana}

2 to $3 \mathrm{ft} . \ldots \ldots \ldots \ldots \ldots \ldots \ldots$

3 to $4 \mathrm{ft} \ldots \ldots \ldots \ldots \ldots \ldots \ldots$

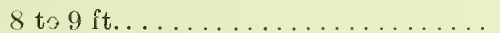

9 to $10 \mathrm{ft} \ldots \ldots \ldots \ldots \ldots \ldots \ldots$

10 to $12 \mathrm{ft} . \ldots \ldots \ldots \ldots \ldots \ldots \ldots$

12 to $14 \mathrm{ft} . \ldots \ldots \ldots \ldots \ldots \ldots \ldots$

densiflora

2 to $3 \mathrm{ft} \ldots \ldots \ldots \ldots \ldots \ldots \ldots$

3 to $4 \mathrm{ft}$.

montana

2 to $2 \frac{1}{2} \mathrm{ft} . \ldots \ldots \ldots \ldots \ldots \ldots$

$21 / 2$ to $3 \mathrm{ft} . \ldots \ldots \ldots \ldots \ldots \ldots$

3 to $4 \mathrm{ft} . \ldots \ldots \ldots \ldots \ldots \ldots \ldots \ldots$

4 to $5 \mathrm{ft} \ldots \ldots \ldots \ldots \ldots \ldots \ldots \ldots$

5 to $6 \mathrm{ft} \ldots \ldots \ldots \ldots \ldots \ldots \ldots \ldots$

mont. mughus

15 to 18 in. spread. . . . . . . . . . .

18 to 24 in. spread............

2 to $21 / 2 \mathrm{ft}$. spread.............

$21 / 2$ to $3 \mathrm{ft}$. spread............

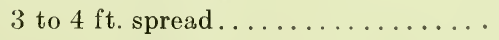

4 to $5 \mathrm{ft}$. spread.
Austrian Pine

$250 \quad 22.50 \quad 20000$

$400 \quad 3600 \quad 32000$

$\begin{array}{llllll}5 & 00 & 46 & 00 & 420 & 00\end{array}$

$\begin{array}{llllll}750 & 70 & 00 & 620 & 00\end{array}$

$1000 \quad 9000$

1400

Jack Pine

100

150

400

500

600

$800 \quad 7000$

Japanese Red Pine

$\begin{array}{llllll}1 & 75 & 16 & 00 & 120 & 00\end{array}$

$250 \quad 2200 \quad 20000$

Mountain Pine

$300 \quad 2800$

$\begin{array}{llll}4 & 00 & 36 & 00\end{array}$

$\begin{array}{llll}5 & 00 \quad .600\end{array}$

750

Dwarf Mountain Pine

$\begin{array}{llllll}1 & 75 & 16 & 00 & 140 & 00\end{array}$

$250 \quad 2250 \quad 20000$

$\begin{array}{llllll}3 & 50 & 32 & 50 & 300 & 00\end{array}$

$\begin{array}{llllll}5 & 00 & 45 & 00 & 400 & 00\end{array}$

$\begin{array}{llllll}10 & 00 & 90 & 00 & 800 & 00\end{array}$

1500 
PINUS-continued

monticola (five-leaved)

2 to $2 \frac{1}{2} \mathrm{ft} . \ldots \ldots \ldots \ldots \ldots \ldots \ldots \ldots$

$21 / 2$ to $3 \mathrm{ft} \ldots \ldots \ldots \ldots \ldots \ldots \ldots \ldots$

3 to $4 \mathrm{ft} . \ldots \ldots \ldots \ldots \ldots \ldots \ldots$. 400

resinosa

3 to $4 \mathrm{ft} . \ldots \ldots \ldots \ldots \ldots \ldots \ldots \ldots . \ldots 20$

4 to $5 \mathrm{ft} \ldots \ldots \ldots \ldots \ldots \ldots \ldots \ldots \ldots$

5 to $6 \mathrm{ft} . \ldots \ldots \ldots \ldots \ldots \ldots \ldots \ldots$

strobus

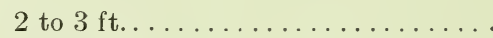

3 to $4 \mathrm{ft} . \ldots \ldots \ldots \ldots \ldots \ldots \ldots$

4 to $5 \mathrm{ft} . \ldots \ldots \ldots \ldots \ldots \ldots \ldots$

7 to $8 \mathrm{ft} . \ldots \ldots \ldots \ldots \ldots \ldots \ldots$

10 to $12 \mathrm{ft}$

12 to $14 \mathrm{ft}$.

sylvestris

2 to $3 \mathrm{ft}$.

3 to $4 \mathrm{ft}$

5 to $6 \mathrm{ft}$.

$6 \mathrm{t}, 7 \mathrm{ft}$

7 to $8 \mathrm{ft}$

PSEUDOTSUGA taxifolia

5 to $6 \mathrm{ft} . \ldots \ldots \ldots \ldots \ldots \ldots \ldots$

6 to $7 \mathrm{ft}$

7 to $8 \mathrm{ft}$

8 to $10 \mathrm{ft}$.

10 to $12 \mathrm{ft}$.

12 to $14 \mathrm{ft}$.

RETINISPORA filifera

$21 / 2$ to $3 \mathrm{ft}$

3 to $4 \mathrm{ft}$. .

3 to $4 \mathrm{ft}$. extra borad

4 to $5 \mathrm{ft}$. extra broad

5 to $6 \mathrm{ft}$. extra broad.

6 to $7 \mathrm{ft}$. extra broad

7 to $8 \mathrm{ft}$. extra broad

fil aurea

18 to 24 in. spread............ 500

2 to $2 \frac{1}{2} \mathrm{ft}$. spread............ 750

$21 / 2$ to $3 \mathrm{ft}$. spread........... 1000

1200
Red or Norway Pine $00 \quad 1750 \quad 150 \quad 00$ $2500 \quad 20000$ 3500

White Pine

$100 \quad 850 \quad 7000$

$\begin{array}{llllll}2 & 00 & 18 & 00 & 160 & 00\end{array}$

$250 \quad 2250 \quad 20000$

750

1000

1400

1800

Scotch Pine

150

250

350

450

600

Doualgs Fir

600

900

1200

1500

2000

2500

Thread-branched Cypress

400

500

600

800

1600

2000 
RETINISPORA - continued

pisifera

$21 / 2$ to $3 \mathrm{ft}$

3 to $4 \mathrm{ft}$.

4 to $5 \mathrm{ft}$

5 to $6 \mathrm{ft}$

6 to $7 \mathrm{ft}$

pis. aurea

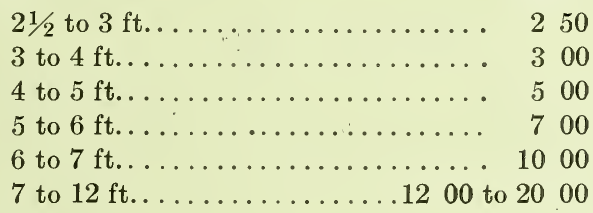

plumosa

2 to $21 / 2 \mathrm{ft}$. sheared specimens ......

$21 / 2$ to $3 \mathrm{ft}$. sheared specimens ......

3 to $4 \mathrm{ft}$. sheared specimens ........

4 to $5 \mathrm{ft}$. sheared specimens........ 500

12 to $14 \mathrm{ft}$. sheared specimens..... 3000

plum. aurea

$21 / 2$ to $3 \mathrm{ft}$. sheared specimens......

3 to $4 \mathrm{ft}$. sheared specimens........

4 to $5 \mathrm{ft}$. sheared specimens........

5 to $6 \mathrm{ft}$. sheared specimens........

6 to $7 \mathrm{ft}$. sheared specimens........

7 to $8 \mathrm{ft}$. sheared specimens........

8 to $9 \mathrm{ft}$. sheared specimens........

9 to $10 \mathrm{ft}$. sheared specimens.......

10 to $12 \mathrm{ft}$. sheared specimens......

squarrosa veitchii

18 to 24 in.....................

2 to $2 \frac{1}{2} \mathrm{ft} . \ldots \ldots \ldots \ldots \ldots \ldots \ldots$

3 to $4 \mathrm{ft} . \ldots \ldots \ldots \ldots \ldots \ldots \ldots$

4 to $5 \mathrm{ft} . \ldots \ldots \ldots \ldots \ldots \ldots \ldots \ldots 100$

5 to $6 \mathrm{ft} . \ldots \ldots \ldots \ldots \ldots \ldots \ldots \ldots$

SCIADOPITYS verticillata

18 to 24 in.

2 to $21 / 2 \mathrm{ft}$.

TAXUS canadensis

15 to 18 in. spread.............

18 to 24 in. spread.............

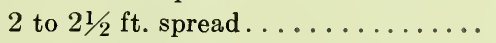

$21 / 2$ to $3 \mathrm{ft}$. spread
Umbrella Pine

Golden Plumed Cypress

$\begin{array}{llll}300 & 2800\end{array}$

$350 \quad 3200$

$500 \quad 4500$

$\begin{array}{llll}7 & 00 & 65 & 00\end{array}$

$1000 \quad 9000$

$1200 \quad 11000$

$1500 \quad 14000$

$2000 \quad 19000$

2500

Gray Cypress

$250 \quad 2250$

$\begin{array}{llll}3 & 00 & 28 & 00\end{array}$

$\begin{array}{llll}7 & 00 & 65 & 00\end{array}$

$1000 \quad 9500$

400

500

American Yew

$150 \quad 1250 \quad 100 \quad 00$

$\begin{array}{llllll}2 & 00 & 18 & 00 & 160 & 00\end{array}$

$\begin{array}{llllll}2 & 50 & 22 & 50 & 200 & 00\end{array}$

$\begin{array}{llllll}3 & 00 & 28 & 00 & 260 & 00\end{array}$ 
TAXUS-continued

cuspidata

15 to 18 in. spread

18 to 24 in. spread.

2 to $2 \frac{1}{2} \mathrm{ft}$. spread

cusp. brevifolia

12 to 15 in

15 to 18 in.

18 to $24 \mathrm{in.}$

Extra Bushy Plants

12 to 15 in spread.......................

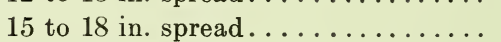

18 to 24 in. spread..............

THUYA occidentalis

$2 \mathrm{ft} . \ldots \ldots \ldots \ldots \ldots \ldots \ldots \ldots \ldots$

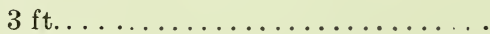

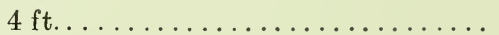

$5 \mathrm{ft} . \ldots \ldots \ldots \ldots \ldots \ldots \ldots \ldots \ldots$

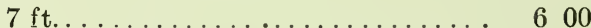

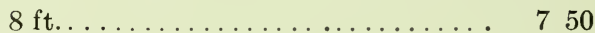

$9 \mathrm{ft} \ldots \ldots \ldots \ldots \ldots \ldots \ldots \ldots, 1000$

$10 \mathrm{ft} \ldots \ldots \ldots \ldots \ldots \ldots \ldots \ldots, 1200$

$12 \mathrm{ft} \ldots \ldots \ldots \ldots \ldots \ldots \ldots \ldots, 1500$

occ. aurea

2 to $3 \mathrm{ft}$

3 to $4 \mathrm{ft}$.

4 to $5 \mathrm{ft}$.

6 to $7 \mathrm{ft}$.

9 to $10 \mathrm{ft}$. .

10 to $12 \mathrm{ft}$.

occ. columbia

18 to 24 in.

2 to $3 \mathrm{ft}$

3 to $4 \mathrm{ft}$.

4 to $5 \mathrm{ft}$

occ. cristata

15 to $18 \mathrm{in}$.

18 to 24 in.

occ. douglasi pyramidalis

3 to $4 \mathrm{ft}$.

4 to $5 \mathrm{ft}$

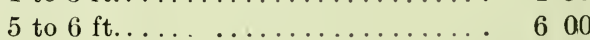

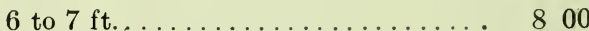

8 to $9 \mathrm{ft} . \ldots \ldots \ldots \ldots \ldots \ldots \ldots . \ldots 1200$

8 to $9 \mathrm{ft} \ldots \ldots \ldots \ldots \ldots \ldots \ldots \ldots \ldots$
9 to $10 \mathrm{ft} . \ldots \ldots \ldots \ldots \ldots \ldots$
Dwarf Japanese Yew

$200 \quad 1800$

$250 \quad 2250$

$250 \quad 2400$

$350 \quad 3200$

American Arborvitae

$\begin{array}{llllll}125 & 11 & 00 & 100 & 00\end{array}$

$150 \quad 13 \quad 50 \quad 12000$

$\begin{array}{llll}3 & 00 & 28 & 00\end{array}$

Peabody's Golden Arborvitae

150

1250

200

300

500

800

1000

Gold-tipped Arborvitae

$125 \quad 1000$

$150 \quad 1250$

$200 \quad 1800$

300

\section{Crested Arborvitae}

$150 \quad 1250$

$200 \quad 1800$

Douglas Pyramidal Arborvitae 300

50

00 
THUYA-continued

occ. ellwangeriana

18 to 24 in.................... 150

2 to $21 / 2 \mathrm{ft} \ldots \ldots \ldots \ldots \ldots \ldots \ldots . .200$

$21 / 2$ to $3 \mathrm{ft} . \ldots \ldots \ldots \ldots \ldots \ldots \ldots .300$

occ. globosa

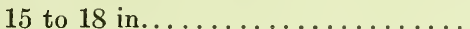

18 to 24 in

2 to $2 \frac{1}{2} \mathrm{ft}$

$21 / 2$ to $3 \mathrm{ft}$

occ. pyramidalis

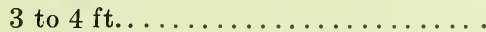

4 to $5 \mathrm{ft} . \ldots \ldots \ldots \ldots \ldots \ldots \ldots \ldots$

5 to $6 \mathrm{ft}$.

6 to $7 \mathrm{ft} . \ldots \ldots \ldots \ldots \ldots \ldots . . .60$

occ. siberica

2 to $21 / 2 \mathrm{ft} . \ldots \ldots \ldots \ldots \ldots \ldots \ldots$. . . . .

$21 / 2$ to $3 \mathrm{ft} . \ldots \ldots \ldots \ldots \ldots \ldots$

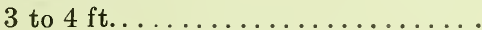

4 to $5 \mathrm{ft} . \ldots \ldots \ldots \ldots \ldots \ldots \ldots$

5 to $6 \mathrm{ft}$.

occ. vervaeneana

2 to $3 \mathrm{ft}$.

3 to $4 \mathrm{ft}$.

4 to $5 \mathrm{ft}$.

5 to $6 \mathrm{ft}$.

orientalis

3 to $4 \mathrm{ft}$.

4 to $5 \mathrm{ft}$.

5 to $6 \mathrm{ft}$.

6 to $7 \mathrm{ft}$

TSUGA canadensis

2 to $21 / 2 \mathrm{ft} . \ldots \ldots \ldots \ldots \ldots \ldots$. . . . . . . . . . . . . . . . . . .

$21 / 2$ to $3 \mathrm{ft} . \ldots \ldots \ldots \ldots \ldots \ldots \ldots$.

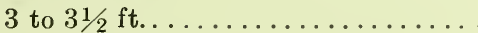

$31 / 2$ to $4 \mathrm{ft} . \ldots \ldots \ldots \ldots \ldots \ldots \ldots$.

$31 / 2$ to $4 \mathrm{ft}$. extra broad............

4 to $5 \mathrm{ft} . \ldots \ldots \ldots \ldots \ldots \ldots \ldots$.

4 to $5 \mathrm{ft}$. extra broad.

5 to $6 \mathrm{ft}$.

5 to $6 \mathrm{ft}$. extra broad

6 to $7 \mathrm{ft}$.

7 to $8 \mathrm{ft}$......

diversifolia

18 to 24 in.
Globe Arborvitae

$\begin{array}{rrrrrr}1 & 50 & -12 & 50 & 100 & 00 \\ 2 & 50 & 22 & 50 & 200 & 00 \\ 3 & 50 & 32 & 00 & 280 & 00 \\ 5 & 00 & 45 & 00 & & \end{array}$

Pyramidal Arborvitae

$250 \quad 2250 \quad 20000$

$\begin{array}{llllll}4 & 00 & 36 & 00 & 320 & 00\end{array}$

$\begin{array}{llll}6 & 00 & 55 & 00\end{array}$

Siberian Arborvitae

$\begin{array}{llllll}2 & 00 & 18 & 00 & 160 & 00\end{array}$

$250 \quad 2250 \quad 200 \quad 00$

$\begin{array}{llllll}3 & 50 & 32 & 50 & 300 & 00\end{array}$

$\begin{array}{llllll}5 & 00 & 45 & 00 & 400 & 00\end{array}$

750

Vervaen's Arborvilae

$\begin{array}{llll}2 & 00 & 18 & 00 \\ 2 & 75 & 26 & 00 \\ 3 & 50 & & \\ 5 & 00 & & \end{array}$

Chinese Arborvilae

400

$\begin{array}{llll}5 & 00 & 46 & 00\end{array}$

700

1000

American Hemluck

$\begin{array}{llllll}2 & 00 & 18 & 00 & 160 & 00\end{array}$

$\begin{array}{llllll}3 & 00 & 28 & 00 & 260 & 00\end{array}$

$\begin{array}{llllll}3 & 50 & 32 & 00 & 300 & 00\end{array}$

$\begin{array}{llllll}4 & 50 & 42 & 00 & 400 & 00\end{array}$

$\begin{array}{llllll}6 & 00 & 55 & 00 & 500 & 00\end{array}$

$\begin{array}{llllll}6 & 00 & 55 & 00 & 500 & 00\end{array}$

$\begin{array}{llllll}7 & 50 & 70 & 00 & 650 & 00\end{array}$

$\begin{array}{llllll}7 & 50 & 70 & 00 & 650 & 00\end{array}$

$\begin{array}{llllll}9 & 00 & 85 & 00 & 800 & 00\end{array}$

$\begin{array}{llllll}9 & 00 & 85 & 00 & 800 & 00\end{array}$

$\begin{array}{llllrl}12 & 00 & 110 & 00 & 1000 & 00\end{array}$

Red-twigged Hemlock

250 


\section{EVERGREEN SHRUBS}

\section{ANDROMEDA - See PIERIS}

\section{BEBERIS ilicifolia}

2 to $21 / 2 \mathrm{ft}$

$21 / 2$ to $3 \mathrm{ft}$

BUXUS arborescens

pyramids

Each Per 10 Per 100

$21 / 2 \mathrm{ft}$

$3 \mathrm{ft}$.

$31 / 2 \mathrm{ft}$.

suffruticosà

4 to 5 in

Dwarf Box Edging

5 to 6 in.

25

200

6 to 8 in

30

250

35

300

CHAMAEDAPHNE calyculata

15 to 18 in.

Leather Leaf

80

700

COTONEASTER horizontalis

12 to 15 in. from pots..........

microphylla

9 to $12 \mathrm{in.} \mathrm{from} \mathrm{pots}$

DAPHNE cneorum

Prostrate Rose Box

75

650

Small-Leaved Rose Box $60 \quad 500$

Garland Flower

6 to 8 in.................. 75

$500 \quad 3500$

8 to $10 \mathrm{in.}$

100

750

5500

10 to 12 in.

125

$1000 \quad 7500$

EUONYMUS radicans

Evergreen Bittersweet

3 yrs. .

50

$400 \quad 3000$

carrieri

Carrier's Evergreen Bittersweet

2 yrs.

40

$300 \quad 2000$

minima (kewensis)

Small-leaved Evergreen Bittersweet

2 yrs. .

50

400

variegata

Variegated Evergreen Bittersweet

2 yrs. 40

300

2000

vegeta

Broad-leaved Evergreen Bittersweet

2 yrs.

300

2000 
KALMIA angustifolia

Sheep Laurel

9 to 12 in................... $100 \quad 800 \quad 6000$

12 to 15 in................... $125 \quad 1000 \quad 7500$

15 to 18 in.................. $150 \quad 1350 \quad 12000$

18 to 24 in................. $175 \quad 1600$

latifolia

15 to 18 in......................

18 to 24 in..................... .

2 to $21 / 2 \mathrm{ft} . \ldots \ldots \ldots \ldots \ldots \ldots \ldots$. . .

LEUCOTHOE catesbaei

12 to $15 \mathrm{in.}$.

15 to 18 in.

PACHYSANDRA terminalis

2 yrs. from pots.

3 yrs. from pots

PIERIS floribunda

12 in. spread............... 200

15 in. spread................ 250

18 in. spread............... 350

24 in. spread............... 500

japonica

Japanese Lily-of-the-valley Shrub

$12 \mathrm{in} . . . \ldots \ldots \ldots \ldots \ldots . . . \ldots . .200$

15 in..................... 300

VINCA minor

2 yrs. from pots.
Mountain Laurel

$\begin{array}{llll}175 & 16 & 00\end{array}$

$250 \quad 2200$

Drooping Andromeda

$\begin{array}{llll}100 & 900\end{array}$

$125 \quad 1000$

Japanese Spurge

$\begin{array}{llll}2 & 00 & 16 & 00\end{array}$

$250 \quad 2000$

Lily-of-the-valley Shrub
$150 \quad 1350$ 


\section{RHODODENDRONS}

Our stock comprises the native varieties, Catawbiense and Maximum as well as the hardiest of the Catawbiense Hybrids. To this list we have recently added Rhododendron Carolinianum, a native sort of great hardiness and beauty.

\begin{tabular}{|c|c|c|}
\hline & Each & Per 10 \\
\hline RHODODENDRON carolinianum - pink & \multicolumn{2}{|c|}{ Carolina Rhod } \\
\hline $15 \mathrm{in} . \ldots \ldots \ldots \ldots \ldots \ldots \ldots \ldots$ & 200 & 1800 \\
\hline 18 in.. & 250 & 2200 \\
\hline $2 \mathrm{ft} .$. & 350 & \\
\hline catawbiense - deep pink & \multicolumn{2}{|c|}{ Catawban Rho } \\
\hline $15 \mathrm{in} . . . \ldots \ldots \ldots$ & \multicolumn{2}{|l|}{125} \\
\hline 18 in. . . . . . . . & \multicolumn{2}{|l|}{175} \\
\hline $2 \mathrm{ft} . \ldots$. & \multicolumn{2}{|l|}{225} \\
\hline maximum - white to blush, late blooming & \multicolumn{2}{|c|}{ Great Laurel } \\
\hline $2 \mathrm{ft} . \ldots \ldots \ldots \ldots \ldots \ldots \ldots \ldots \ldots$ & 250 & 2250 \\
\hline $2 \frac{1}{2} \mathrm{ft} . \ldots \ldots \ldots \ldots \ldots$ & 325 & 3000 \\
\hline 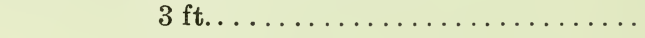 & 375 & 3500 \\
\hline $31 / 2 \mathrm{ft} \ldots \ldots \ldots \ldots \ldots \ldots \ldots$ & 350 & 4000 \\
\hline $4 \mathrm{ft} . \ldots \ldots \ldots \ldots$ & 600 & 5000 \\
\hline \multicolumn{3}{|c|}{ Extra Bushy Specimens } \\
\hline $18 \mathrm{in} . \ldots \ldots \ldots \ldots \ldots$ & 250 & 2200 \\
\hline$\ldots \ldots \ldots \ldots \ldots$ & 350 & 3200 \\
\hline $21 / 2 \mathrm{ft} . \ldots \ldots \ldots \ldots$ & 450 & 4200 \\
\hline $3 \mathrm{ft} .$. & 700 & 6500 \\
\hline $31 / 2 \mathrm{f}$ & 1000 & \\
\hline
\end{tabular}

\section{GATAWBIENSE HYBRIDS}

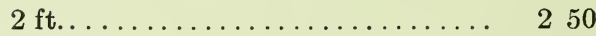

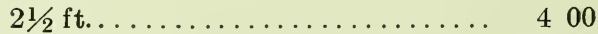

$3 \mathrm{ft} . \ldots \ldots \ldots \ldots \ldots \ldots \ldots, 600 . \ldots \ldots$

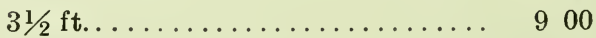

If we have not in stock the size of any variety ordered we shall select the sort most nearly approaching the desired color, UNLESS OTHERWISE SPECIFIED.

ABRAHAM LINCOLN - Rosy Red

ALBUM ELEGANS - Blush White

ALBUM GRANDIFLORUM - large White 
- BOULE DE NEIGE - Early, white dwarf. This sort is measured by breadth rather than height.

CARACTACUS - Medium Red

CATAWBIENSE GRANDIFLORA - Rosy purple.

CATAWBIENSE GRANDIFLORA ALBA - White; bright yellow spots

CHARLES BAGLEY - Crimson

CHARLES DICKENS - Bright Crimson; mahogany spots

DELICATISSIMUM - Blush

EDWARD S. RAND - Clear light red

EVERESTIANUM - Rosy Lilac; edges crimped

F. D. GODMAN - Medium Red; dark spots

HANNA FELIX — Dark pure pink; mahogany spots

KETTLEDRUM - Medium red; purple tinge

LADY ARMSTRONG - Deep pink; dark spots

LADY CLERMONT — Dark red

LADY GREY EGERTON — Large blush lilac

MRS. MILNER - Large bright red

PARSONS' GLORIOSUM - Blush lilac; yellow spots

PRESIDENT LINCOLN - Pale rosy lilac

ROSEUM ELEGANS - Deep rose; lavender tinge 


\section{DEGIDUOUS SHADE AND ORNAMENTAL TREES}

Varieties marked "B \& B" are always dug with Ball \& Burlap at No Additional Cost.

ACANTHOPANAX maximowiczii

Each Per 10 Per 100

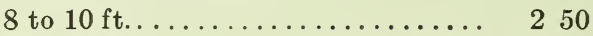

10 to $12 \mathrm{ft} . \ldots \ldots \ldots \ldots \ldots \ldots \ldots . .350$

ACER dasycarpum

Silver Maple

10 to $12 \mathrm{ft.} 1 \frac{1}{2}$ to $13 / 4$ in. cal....... $175 \quad 1600 \quad 12000$

12 to $14 \mathrm{ft.} 13 / 4$ to 2 in. cal......... $200 \quad 1800 \quad 14000$

14 to $16 \mathrm{ft} .2$ to $2 \frac{1}{2}$ in. cal.......... $250 \quad 2200 \quad 20000$

16 to $18 \mathrm{ft} .2 \frac{1}{2}$ to 3 in. cal......... $400 \quad 3500$

Specimens 3 to 4 in. cal......... $700 \quad 6000$

dasy. wieri

8 to $10 \mathrm{ft} .1$ to $1 \frac{1}{4}$ in. cal.......... 150

10 to $12 \mathrm{ft.} 1 \frac{1}{4}$ to $1 \frac{1 / 2}{2}$ in. cal....... . $200 \quad 1800$

12 to $14 \mathrm{ft}$. $1 \frac{1 / 2}{2}$ to $13 / 4$ in. cal....... $300 \quad 2600$

14 to $16 \mathrm{ft} .13 / 4$ to 2 in. cal........ 400

16 to $18 \mathrm{ft} .2$ to $2 \frac{1}{2}$ in. cal........ 500 negundo

6 to $8 \mathrm{ft} . \ldots \ldots \ldots \ldots \ldots \ldots . \ldots . \ldots 150$

neg. argentea

6 to $8 \mathrm{ft} . \ldots \ldots \ldots \ldots \ldots \ldots \ldots . \ldots 200 \quad 1800$

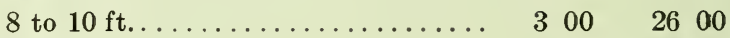

neg. aurea

Golden Ash-leaved Maple

6 to $8 \mathrm{ft} . \ldots \ldots \ldots \ldots \ldots \ldots . \ldots 200 \quad 1800$

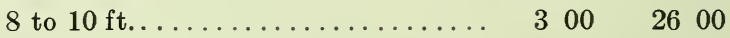

platanoides

Norway Maple

8 to $10 \mathrm{ft.} 1$ to $1 \frac{1 / 4}{4}$ in. cal.......... $150 \quad 1250 \quad 10000$

10 to $12 \mathrm{ft.} 1 \frac{1}{4}$ to $1 \frac{1}{2}$ in. cal....... $175 \quad 1600 \quad 12000$

12 to $14 \mathrm{ft} .1 \frac{1}{2}$ to $13 / 4$ in. cal....... $200 \quad 1800 \quad 16000$

12 to $14 \mathrm{ft} .13 / 4$ to 2 in. cal......... $300 \quad 2800 \quad 26000$

14 to $16 \mathrm{ft} .2$ to $2 \frac{1}{2}$ in. cal........ . $400 \quad 3600 \quad 32000$

16 to $18 \mathrm{ft} .2 \frac{1}{2}$ to 3 in. cal........ $600 \quad 5500$

16 to $18 \mathrm{ft} .3$ to $31 / 2$ in. cal......... 1000

18 to $20 \mathrm{ft} .31 / 2$ to 4 in. cal........ 2000

plat. schwedleri

Purple Norway Maple

10 to $12 \mathrm{ft} .1 \frac{1}{4}$ to $1 \frac{1}{2}$ in. cal....... 250

12 to $14 \mathrm{ft} .1 \frac{1}{2}$ to $1 \frac{13}{4}$ in. cal....... 350

12 to $14 \mathrm{ft} .13 / 4$ to 2 in. cal......... 425

14 to $16 \mathrm{ft} .2$ to $2 \frac{1}{2}$ in. cal......... 500

16 to $18 \mathrm{ft} .2 \frac{1}{2}$ to $3 \mathrm{in}$. cal........ 700 
ACER-continued

rubrum

10 to $12 \mathrm{ft} . \ldots \ldots \ldots \ldots \ldots \ldots \ldots . \ldots 250$

12 to $14 \mathrm{ft} . \ldots \ldots \ldots \ldots \ldots \ldots \ldots . \ldots . \ldots$

14 to $16 \mathrm{ft} . \ldots \ldots \ldots \ldots \ldots \ldots \ldots \ldots$

saccharum

10 to $12 \mathrm{ft} .1 \frac{1}{4}$ to $1 \frac{1}{2}$ in. cal.......

12 to $14 \mathrm{ft} .1 \frac{1}{2}$ to $13 / 4$ in. cal.......

14 to $16 \mathrm{ft} .13 / 4$ to 2 in. cal.........

14 to $16 \mathrm{ft} .2$ to $2 \frac{1}{2}$ in. cal.........

16 to $18 \mathrm{ft} .2 \frac{1}{2}$ to 3 in. cal.........

16 to $18 \mathrm{ft.} 3$ to $3 \frac{1}{2}$ in. cal......... 1200

18 to $24 \mathrm{ft} .31 / 2$ to 4 in. cal......... 2000

tataricum ginnala

3 to $4 \mathrm{ft} . . \ldots \ldots \ldots \ldots \ldots \ldots \ldots$

4 to $5 \mathrm{ft} . \ldots \ldots \ldots \ldots \ldots \ldots \ldots$

5 to $6 \mathrm{ft} . \ldots \ldots \ldots \ldots \ldots \ldots \ldots$

AESCULUS hippocastanum

6 to $8 \mathrm{ft}$. .

8 to $10 \mathrm{ft} . \ldots \ldots \ldots \ldots \ldots \ldots \ldots$

10 to $12 \mathrm{ft.} 2$ to $2 \frac{1}{2}$ in. cal.........

12 t, $14 \mathrm{ft.} 2 \frac{1}{2}$ to 3 in. cal........

14 to $16 \mathrm{ft} .3$ to 4 in. cal........... 1000

Specimens 4 to 5 in. cal. ......... 2000

pavia carnea

8 to $10 \mathrm{ft} . \ldots \ldots \ldots \ldots \ldots \ldots \ldots \ldots$

10 to $12 \mathrm{ft} . \ldots \ldots \ldots \ldots \ldots \ldots \ldots \ldots$

12 to $14 \mathrm{ft} . \ldots \ldots \ldots \ldots \ldots \ldots \ldots$

ARALIA spinosa

3 to $4 \mathrm{ft} . \ldots \ldots \ldots \ldots \ldots \ldots \ldots$

BETULA alba laciniata

10 to $12 \mathrm{ft} . . \ldots \ldots \ldots \ldots \ldots \ldots$. . . . . . . . .

12 to $14 \mathrm{ft} . \ldots \ldots \ldots \ldots \ldots \ldots \ldots$

14 to $16 \mathrm{ft} . \ldots \ldots \ldots \ldots \ldots \ldots \ldots$.

lenta

8 to $10 \mathrm{ft}$.

10 to $12 \mathrm{ft}$.

lutea

10 to $12 \mathrm{ft}$

12 to $14 \mathrm{ft}$

papyracea

8 to $10 \mathrm{ft}$

10 to $12 \mathrm{ft}$.

12 to $14 \mathrm{ft} . \ldots \ldots \ldots \ldots \ldots \ldots \ldots \ldots$

14 to $16 \mathrm{ft} . \ldots \ldots \ldots \ldots \ldots \ldots \ldots$

16 to $18 \mathrm{ft}$.
Sugar Maple

$\begin{array}{llll}200 & 1600\end{array}$

$250 \quad 2200$

13000

20000

$\begin{array}{lllll}300 & 28 & 00 & 260 & 00\end{array}$

$\begin{array}{llllll}5 & 00 & 40 & 00 & 360 & 00\end{array}$

$700 \quad 6000$

Tatarian Maple

$80 \quad 700 \quad 6000$

$100 \quad 850 \quad 7000$

$\begin{array}{llllll}1 & 25 & 10 & 00 & 85 & 00\end{array}$

Horse Chestnut

$\begin{array}{llll}200 & 1800\end{array}$

$\begin{array}{llll}3 & 00 & 28 & 00\end{array}$

$\begin{array}{llll}4 & 00 & 36 & 00\end{array}$

$\begin{array}{llll}5 & 00 & 4500\end{array}$

$00 \quad 90 \quad 00$

Red Buckeye

\section{Hercules Club}

100

Cut-leaved Weeping Birch

$300 \quad 2500$

$\begin{array}{llll}4 & 00 & 35 & 0.0\end{array}$

$500 \quad 4400$

Black Birch

$150 \quad 1200$

$\begin{array}{llll}2 & 00 & 18 & 00\end{array}$

Yellow Birch

$250 \quad 2200$

$350 \quad 3200$

Canoe Birch

$\begin{array}{llll}175 & 1500\end{array}$

$225 \quad 2000$

$300 \quad 2600$

$400 \quad 3500$

$500 \quad 4500$ 


\section{CARPINUS americanus}

5 to $6 \mathrm{ft}$. $\mathrm{B} \& \mathrm{~B}$

6 to $7 \mathrm{ft} . \mathrm{B} \& \mathrm{~B}$

7 to $8 \mathrm{ft}$. B\&B

8 to $10 \mathrm{ft}$. B \& B

betulus

4 to $5 \mathrm{ft}$. B \& B

5 to $6 \mathrm{ft}$. $\mathrm{B} \& \mathrm{~B}$

6 to $7 \mathrm{ft} . \mathrm{B} \& \mathrm{~B}$

7 to $8 \mathrm{ft}$. $B \& B$

8 to $9 \mathrm{ft}$. B\&B

CATALPA speciosa

10 to $12 \mathrm{ft}$

14 to $16 \mathrm{ft}$

CERASUS avium fl. pl. alba

4 to $5 \mathrm{ft}$. B \& B

5 to $6 \mathrm{ft}, \mathrm{B} \& \mathrm{~B}$

japonica fl. pl. alba

6 to $7 \mathrm{ft}$. B \&B

7 to $8 \mathrm{ft}$. B \&B

jap. hisakura

6 to $8 \mathrm{ft}$. B \& B

8 to $10 \mathrm{ft} . \mathrm{B} \& \mathrm{~B}$

jap. pumila

8 year heads grafted on 5 to $6 \mathrm{ft}$. stems B \& B .

CERCIS canadensis

3 to $4 \mathrm{ft}$.

CHIONANTHUS virginica

2 to $3 \mathrm{ft}$. .

3 to $4 \mathrm{ft}$

CLADRASTIS tinctoria

6 to $8 \mathrm{ft}$.

8 to $10 \mathrm{ft}$

CORNUS florida

2 to $3 \mathrm{ft}$. B\&B

3 to $4 \mathrm{ft}$. B \& B

4 to $5 \mathrm{ft}$. B \& B

5 to $6 \mathrm{ft}$. B\&B

flor. rubra

2 to $3 \mathrm{ft}$. B \& B

3 to $4 \mathrm{ft} . \mathrm{B} \& \mathrm{~B}$

4 to $5 \mathrm{ft} . \mathrm{B} \& \mathrm{~B}$

5 to $6 \mathrm{ft}$. B\&B
Each Per 10 Per 100

American Hornbeam

$100 \quad 800$

$125 \quad 1000$

$\begin{array}{llll}1 & 75 & 15 & 00\end{array}$

$250 \quad 2200$

European Hornbeam

$80 \quad 650$

$100 \quad 800$

$125 \quad 1000$

$175 \quad 1500$

$250 \quad 2200$

Indian Bean

$200 \quad 1800$

$\begin{array}{llll}3 & 00 & 28 & 00\end{array}$

$400^{\circ} \quad 3600$

Double White Flowering Cherry 400

500

White Japanese Cherry

600

800

Deep Pink Cherry

600

800

Dwarf Japanese Cherry

800

Red Bud

$75 \quad 600$

White Fringe

60

75

Yellow Wood

250

350

White Flowering Dogwood

80

700

100

150

200

Pink Florweing Dogwood

125

$\begin{array}{llll}1 & 75 & 16 & 00\end{array}$

$\begin{array}{llll}3 & 00 & 28 & 00\end{array}$

400 


\section{CRATAEGUS carrieri}

5 to $6 \mathrm{ft}$. B \&B.

6 to $8 \mathrm{ft}$. B \& B

8 to $10 \mathrm{ft}$. B \&B.

10 to $12 \mathrm{ft}$. B \&B

Each Per 10 Per 100 Carrier's Thorn

200

250

350

500

coccinea

\begin{tabular}{|c|c|c|}
\hline ft. & 100 & 900 \\
\hline & 150 & 1250 \\
\hline & 200 & 1800 \\
\hline $\mathrm{ft} . \ldots \ldots \ldots \ldots \ldots \ldots \ldots$ & 300 & \\
\hline
\end{tabular}

cordata

4 to $5 \mathrm{ft} . \mathrm{B} \& \mathrm{~B}$

Washington Thorn

5 to $6 \mathrm{ft} . \mathrm{B} \& \mathrm{~B}$

$100 \quad 900$

$150 \quad 1250$

6 to $8 \mathrm{ft}$. B \& B

$225 \quad 2000$

8 t) $10 \mathrm{ft} . \mathrm{B} \& \mathrm{~B}$

$\begin{array}{llll}3 & 00 & 26 & 00\end{array}$

10 to $12 \mathrm{ft}$. B\&B

$400 \quad 3500$

crus-galli

4 to $5 \mathrm{ft} . \ldots \ldots \ldots \ldots \ldots \ldots \ldots \ldots$

Cockspur Thorn

5 to $6 \mathrm{ft} . \ldots \ldots \ldots \ldots \ldots \ldots \ldots$

6 to $7 \mathrm{ft.} \ldots \ldots \ldots \ldots \ldots \ldots \ldots \ldots$

7 to $8 \mathrm{ft} . \ldots \ldots \ldots \ldots \ldots \ldots \ldots$

oxyacantha

7 to $8 \mathrm{ft}$. B \& B

$\begin{array}{rrrrrr}1 & 00 & 9 & 00 & 80 & 00 \\ 1 & 50 & 12 & 00 & 100 & 00\end{array}$

$\begin{array}{llllll}2 & 00 & 18 & 00 & 150 & 00\end{array}$

$250 \quad 2200$

8 to $9 \mathrm{ft}$. B \&B

Common Hawthorn

$250 \quad 2200$

$\begin{array}{llll}3 & 00 & 28 & 00\end{array}$

9 to $10 \mathrm{ft}$. B\&B............ $400 \quad 3600$

10 to $12 \mathrm{ft} . \mathrm{B} \& \mathrm{~B}$.

$600 \quad 5500$

oxy. fl. pl. alba

10 to $12 \mathrm{ft}$. B \&B

Double White Hawthorn 600

oxy. fl. pl. pauli

Paul's Double Scarlet Thorn

3 to $4 \mathrm{ft}$. B \& B

$\begin{array}{llll}125 & 1000\end{array}$

$175 \quad 1500$

4 to $5 \mathrm{ft}$. B \& B

6 to $7 \mathrm{ft} . \mathrm{B} \& \mathrm{~B} \ldots \ldots \ldots \ldots \ldots \ldots \ldots \ldots \ldots \ldots \ldots \ldots \ldots$
7 to $8 \mathrm{ft} . \mathrm{B} \& \mathrm{~B} \ldots \ldots \ldots \ldots \ldots$

9 to $10 \mathrm{ft} . \mathrm{B} \& \mathrm{~B} \ldots \ldots \ldots \ldots \ldots \ldots \ldots . \ldots 1000$

10 to $12 \mathrm{ft} . \mathrm{B} \& \mathrm{~B} \ldots \ldots \ldots \ldots \ldots \ldots \ldots 1500$

FAGUS grandifolia

American Beech

5 to $6 \mathrm{ft} \ldots \ldots \ldots \ldots \ldots \ldots \ldots \ldots . \ldots 250 \quad 2250 \quad 20000$

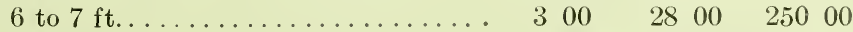

7 to $8 \mathrm{ft} . \ldots \ldots \ldots \ldots \ldots \ldots \ldots \ldots+400 \quad 3600 \quad 32000$

8 to $9 \mathrm{ft} . \mathrm{B} \& \mathrm{~B} \ldots \ldots \ldots \ldots \ldots \ldots \ldots .500 \quad 4500 \quad 40000$

9 to $10 \mathrm{ft} . \mathrm{B} \& \mathrm{~B} \ldots \ldots \ldots \ldots \ldots \ldots \ldots . \ldots \ldots 00$

10 to $12 \mathrm{ft}$. B \& B........... 1000 
FAGUS-continued

sylvatica purpurea pendula

6 to $7 \mathrm{ft}$. B\&B.

7 to $8 \mathrm{ft}$. B \& B

8 to $9 \mathrm{ft}, \mathrm{B} \& \mathrm{~B} \ldots \ldots \ldots \ldots \ldots \ldots \ldots$

syl. purp. riversi

8 to $9 \mathrm{ft} . \mathrm{B} \& \mathrm{~B}$

9 to $10 \mathrm{ft}$. B \& B.

10 to $11 \mathrm{ft}$. B \&B

11 to $12 \mathrm{ft}$. B \&B

FRAXINUS alba

8 to $10 \mathrm{ft}$

10 to $12 \mathrm{ft} \ldots \ldots \ldots \ldots \ldots \ldots$

12 to $14 \mathrm{ft} . \ldots \ldots \ldots \ldots \ldots \ldots \ldots . . . . .$.

JUGLANS cinerea

3 to $4 \mathrm{ft} . \ldots \ldots \ldots \ldots \ldots \ldots$

KOELREUTERIA paniculata

3 to $4 \mathrm{ft} . . \ldots \ldots \ldots \ldots \ldots \ldots$.

4 to $5 \mathrm{ft} . \ldots \ldots \ldots \ldots \ldots \ldots \ldots$

5 to $6 \mathrm{ft} \ldots \ldots \ldots \ldots \ldots \ldots \ldots$

LARIX europaea

3 to $4 \mathrm{ft} . \mathrm{B} \& \mathrm{~B}$

MAGNOLIA soulangeana

3 to $4 \mathrm{ft}$. B \& B

4 to $5 \mathrm{ft}$. B \& B

stellata

$21 / 2$ to $3 \mathrm{ft} . \mathrm{B} \& \mathrm{~B}$

3 to $4 \mathrm{ft}$. B \& B

4 to $5 \mathrm{ft}$. B \&B

MALUS floribunda

7 to $8 \mathrm{ft}$. B \& B

8 to $9 \mathrm{ft}$. B \& B

flor. atrosanguinea

7 to $8 \mathrm{ft}$. B \&B

flor. niedwetzkyana

5 to $6 \mathrm{ft}$. B \& B ioensis fl. pl.

3 to $4 \mathrm{ft} . \mathrm{B} \& \mathrm{~B}$

4 to $5 \mathrm{ft}$. B \& B

spectabilis

7 to $8 \mathrm{ft} . \mathrm{B} \& \mathrm{~B}$

spect. fl. pl. alba

10 to $12 \mathrm{ft} . \mathrm{B} \& \mathrm{~B}$
Each Per 10 Per 100

Weeping Purple Beech

800

1000

1200

1000

1500

1800

2400

American or White Ash

$\begin{array}{llll}150 & 12 & 00\end{array}$

$200 \quad 1800$

$\begin{array}{llll}3 & 00 & 28 & 00\end{array}$

\section{Butternut}

$\begin{array}{llll}1 & 00 & 9 & 00\end{array}$

Varnish Tree

100

$\begin{array}{llll}125 & 1000\end{array}$

$\begin{array}{llll}175 & 1600\end{array}$

European Larch

$80 \quad 700$

Soulange's Magnolia

400

600

Hall's Magnolia

500

700

1000

\section{Flowering Crab}

$\begin{array}{ll}400 & 3500\end{array}$

$\begin{array}{llll}6 & 00 & 5500\end{array}$

\section{Crimson Crab}

$400 \quad 3500$

Niedwetzky's Crab 300

Bechtel's Double Flowering Crab

$150 \quad 1200$

$200 \quad 1600$

Chinese Crab

400

Double White Chinese Crab 600 
POPULUS alba

3 to $4 \mathrm{ft}$

alba canescens

14 to $16 \mathrm{ft}$.

deltoides

6 to $8 \mathrm{ft} . \ldots \ldots \ldots \ldots \ldots \ldots$

8 to $10 \mathrm{ft}$.

10 to $12 \mathrm{ft}$.

\section{fastigiata}

6 to $8 \mathrm{ft}$

8 to $10 \mathrm{ft}$.

10 to $12 \mathrm{ft} .1 \frac{1}{4}$ to $1 \frac{1}{2}$ in. cal.......

12 to $14 \mathrm{ft} .1 \frac{1}{2}$ to 2 in. cal.........

14 to $16 \mathrm{ft} .2$ to $2 \frac{1}{2}$ in. cal.........

PRUNUS pissardi

3 to $4 \mathrm{ft} . \ldots \ldots \ldots \ldots \ldots \ldots \ldots \ldots$

5 to $6 \mathrm{ft}$

6 to $7 \mathrm{ft}$.

7 to $8 \mathrm{ft}$

PTLEA trifoliata

4 to $5 \mathrm{ft}$.

5 to $6 \mathrm{ft}$.

QUERCUS palustris

8 to $10 \mathrm{ft} .1 \frac{1}{4}$ to $1 \frac{1}{2}$ in. cal........

10 to $12 \mathrm{ft} .1 \frac{1}{2}$ to 2 in. cal.........

12 to $14 \mathrm{ft} .2$ to $21 / 2$ in. cal..........

14 to $16 \mathrm{ft} .21 / 2$ to 3 in. cal.........

16 to $18 \mathrm{ft} .3$ to 4 in. cal........... 10

robur

6 to $8 \mathrm{ft}$

8 to $10 \mathrm{ft}$

rubra

8 to $10 \mathrm{ft} .1 \frac{1}{4}$ to $1 \frac{1}{2}$ in. cal........

10 to $12 \mathrm{ft} .1 \frac{1}{2}$ to 2 in. cal.........

12 to $14 \mathrm{ft} .2$ to $21 / 2$ in. cal.........

14 to $16 \mathrm{ft} .21 / 2$ to 3 in. cal.........

16 to $20 \mathrm{ft}$. 3 to 4 in. cal
Each Per 10 Per 100

White Poplar

$60 \quad 500$

Gray Poplar

$350 \quad 3000$

Carolina Poplar

$80 \quad 700 \quad 6000$

$100 \quad 850 \quad 7000$

$\begin{array}{llllll}150 & 1200 & 8500\end{array}$

Lombardy Poplar

$\begin{array}{lllll}75 & 700 & 60 & 00\end{array}$

$\begin{array}{llllll}100 & 900 & 7500\end{array}$

$\begin{array}{llllll}125 & 10 & 00 & 90 & 00\end{array}$

$\begin{array}{llllll}175 & 16 & 00 & 120 & 00\end{array}$

$250 \quad 2200 \quad 20000$

Purple-leaved Plum

$80 \quad 700$

$125 \quad 1000$

$150 \quad 1200$

$200 \quad 1600$

Hop Tree

$\begin{array}{llll}1 & 00 & 8 & 00\end{array}$

$150 \quad 1200$

Pin Oak

$250 \quad 2200$

$\begin{array}{llll}3 & 00 & 28 & 00\end{array}$

$\begin{array}{llll}4 & 50 & 42 & 00\end{array}$

$\begin{array}{llll}6 & 00 & 5500\end{array}$

$\begin{array}{lll}0 & 00 \quad 9000\end{array}$

English Oak

200

300

Red Oak

$250 \quad 2200 \quad 20000$

$\begin{array}{llllll}3 & 00 & 28 & 00 & 260 & 00\end{array}$

$\begin{array}{llll}4 & 50 \quad 42 & 00\end{array}$

$600 \quad 5500$

1000 
SALIX alba

4 to $5 \mathrm{ft} . \ldots \ldots \ldots \ldots \ldots \ldots \ldots$

5 to $6 \mathrm{ft}$.

6 to $8 \mathrm{ft}$

babylonica

6 to $8 \mathrm{ft}$

pentandra

5. to $6 \mathrm{ft}$

6 to $8 \mathrm{ft}$.

8 to $10 \mathrm{ft}$.

10 to $12 \mathrm{ft}$.

rosmarinifolia

3 to $4 \mathrm{ft} . . \ldots \ldots \ldots \ldots \ldots \ldots \ldots$

vitellina aurea

5 to $6 \mathrm{ft} . \ldots \ldots \ldots \ldots \ldots \ldots \ldots$

6 to $8 \mathrm{ft} . \ldots \ldots \ldots \ldots \ldots \ldots \ldots$

8 to $10 \mathrm{ft} . \ldots \ldots \ldots \ldots \ldots \ldots \ldots$

Each Per 10 Per 100 White Willow

$50 \quad 4 \quad 00 \quad 3200$

$\begin{array}{lllll}65 & 5 & 50 & 42 & 00\end{array}$

$\begin{array}{lllll}80 & 6 & 50 & 50 & 00\end{array}$

Weeping Willow

$\begin{array}{llllll}1 & 25 & 11 & 00 & 100 & 00\end{array}$

Laurel-leaved Willow

$\begin{array}{lllll}80 & 7 & 00 & 60 & 00\end{array}$

$\begin{array}{llllll}1 & 00 & 9 & 00 & 80 & 00\end{array}$

$\begin{array}{llllll}135 & 1200 & 100 & 00\end{array}$

$\begin{array}{llllll}1 & 75 & 16 & 00 & 120 & 00\end{array}$

Rosemary Willow 80.

Golden-barked Willow 75

600 5000

100

$8 \begin{array}{llll}80 & 70 & 00\end{array}$

$\begin{array}{lllll}125 & 1100 \quad 9000\end{array}$

vit. aurea pendula

Weeping Golden-barked Willow

6 to $8 \mathrm{ft}$.

10

850

7000

8 to $10 \mathrm{ft}$.

$\begin{array}{llll}125 & 11 & 00\end{array}$

9000

SASSAFRAS officinalis

6 to $7 \mathrm{ft}$. B \&B

\section{Sassafras}

175

SOPHORA japonica

4 to $5 \mathrm{ft}$.

Pagoda Tree

5 to $6 \mathrm{ft}$

150

1200

6 to $7 \mathrm{ft}$

$225 \quad 2000$

7 to $8 \mathrm{ft}$

300

2800

$\begin{array}{llll}4 & 00 & 3 \dot{6} & 00\end{array}$

SORBUS aucuparia

6 to $8 \mathrm{ft}$

European Mountain Ash

8 to $10 \mathrm{ft}$.

125 1000

10 to $12 \mathrm{ft}$

150

1250

$225 \quad 2000$

quercifolia

Oak-leaved Mountain Ash

8 to $10 \mathrm{ft}$.

200

10 to $12 \mathrm{ft} . \ldots \ldots \ldots \ldots \ldots \ldots \ldots . \ldots$

12 to $14 \mathrm{ft}$

400

SYRINGA japonica

3 to $4 \mathrm{ft}$.

Japanese Tree Lilac

4 to $5 \mathrm{ft}$

100

850

7000

5 to $6 \mathrm{ft}$.

125

1100

$150 \quad 1250$

6 to $8 \mathrm{ft}$.

200

1600

8 to $10 \mathrm{ft}$

250

2000

TAXODIUM distichum

Bald Cypress

6 to $8 \mathrm{ft} \ldots \ldots \ldots \ldots \ldots \ldots \ldots \ldots$

8 to $10 \mathrm{ft} . \ldots \ldots \ldots \ldots \ldots \ldots \ldots \ldots$ 
TILIA americana

10 to $12 \mathrm{ft.} 1 \frac{1 / 2}{2}$ to 2 in. cal........ 250

12 to $14 \mathrm{ft} .2$ to $2 \frac{1}{2}$ in. cal......... 325

dasystyla

14 to $16 \mathrm{ft} .21 / 2$ to 3 in. cal........ $600 \quad 5000$

16 to $18 \mathrm{ft} .3$ to 4 in. cal.......... $1000 \quad 9000$

europaea

10 to $12 \mathrm{ft} .1 \frac{1}{2}$ to 2 in. cal......... $300 \quad 2800 \quad 25000$

14 to $16 \mathrm{ft.} 2 \frac{1}{2}$ to 3 in. cal........ $500 \quad 4500$

eur. argentea

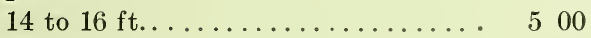

16 to $18 \mathrm{ft} . \ldots \ldots \ldots \ldots \ldots \ldots . .600$

eur. parvifolia

8 to $10 \mathrm{ft} . \ldots \ldots \ldots \ldots \ldots \ldots \ldots$

10 to $12 \mathrm{ft.} 1 \frac{1 / 2}{2}$ to 2 in. cal..........

12 to $14 \mathrm{ft} .2$ to $21 / 2$ in. cal..........

14 to $16 \mathrm{ft} .2 \frac{1}{2}$ to 3 in. cal........ 600

eur. platyphyllos

12 to $14 \mathrm{ft} .2 \frac{1}{2}$ to 3 in. cal........ $500 \quad 5400$

14 to $16 \mathrm{ft.} 3$ to 4 in. cal.......... 700

\section{ULMUS americana}

\section{Small-leaved Linden}

$250 \quad 2250 \quad 20000$

$\begin{array}{llllll}3 & 00 & 28 & 00 & 250 & 00\end{array}$

$\begin{array}{llll}4 & 00 & 36 & 00\end{array}$

Large-leaved Linden

American Elm

$\begin{array}{llllll}1 & 50 & 12 & 00 & 100 & 00\end{array}$

$225 \quad 2000$

$350 \quad 3200$

$500 \quad 4500$

$750 \quad 7000$

16 to $18 \mathrm{ft} .21 / 2$ to 3 in. cal.......... 750
Specimens 3 to 4 in. cal.......... 1000

campestris

12 to $14 \mathrm{ft} .11 / 2$ to 2 in. cal......... 300

14 to $16 \mathrm{ft} .2$ to $2 \frac{1}{2}$ in. cal........ 400

18 to $20 \mathrm{ft}$. 4 to 6 in. cal...... 1500 to 2500

camp. wheatleyi

18 to $20 \mathrm{ft} .2 \frac{1}{2}$ to 3 in. cal........ $600 \quad 5500$ montana

10 to $12 \mathrm{ft} .1 \frac{1}{2}$ to $13 / 4$ in. cal.......

12 to $14 \mathrm{ft} .13 / 4$ to 2 in. cal.........

14 to $16 \mathrm{ft} .2$ to $2 \frac{1}{2}$ in. cal........ 500

mont. fastigiata

18 to $20 \mathrm{ft} .2 \frac{1}{2}$ to 3 in. cal......... presthans

18 to $20 \mathrm{ft} .2 \frac{1}{2}$ to $3 \mathrm{in}$. cal..........
English Elm

Wheatley's Elm

Scotch Elm

$225 \quad 2000$

$350 \quad 3200$

Pyramidal Scotch Elm

$\begin{array}{llll}8 & 00 & 70 & 00\end{array}$

Fastigiate Elm

$\begin{array}{llll}8 & 00 & 70 & 00\end{array}$ 


\section{DEGIDUOUS FLOWERING AND ORNAMENTAL SHRUBS}

Varieties marked "B\&B" are always dug with Ball and Burlap at No Additional Cost.

ACANTHOPANAX pentaphyllum (Aralia)

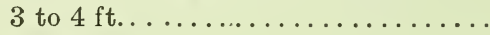

4 to $5 \mathrm{ft} . \ldots \ldots \ldots \ldots \ldots \ldots \ldots \ldots$

sessiliflorum

3 to $4 \mathrm{ft} . \ldots \ldots \ldots \ldots \ldots \ldots \ldots$.

4 to $5 \mathrm{ft} . \ldots \ldots \ldots \ldots \ldots \ldots \ldots \ldots \ldots$

AMELANCHIER canadensis

2 to $3 \mathrm{ft} . \ldots \ldots \ldots \ldots \ldots \ldots \ldots$

3 to $4 \mathrm{ft} . . \ldots \ldots \ldots \ldots \ldots \ldots \ldots$

AMORPHA canescens

2 to $3 \mathrm{ft} . . . \ldots \ldots \ldots \ldots . . . . .$.
Each Per 10 Per 100

Five-leaved Aralia

$50 \quad 400 \quad 3000$

$\begin{array}{llll}60 & 500 \quad 4000\end{array}$

Black-fruited Aralia

$50 \quad 400 \quad 3000$

$60 \quad 500 \quad 4000$

Shad Bush

$\begin{array}{lllll} & 3 & 50 & 25 & 00 \\ 50 & 4 & 00 & 30 & 00\end{array}$

Lead Plant

$50 \quad 400 \quad 3000$

ARALIA pentaphylla - see ACANTHOPANAX spinosa - see under Trees

ARONIA arbutifolia

2 to $3 \mathrm{ft} . \ldots \ldots \ldots \ldots \ldots \ldots \ldots$

3 to $4 \mathrm{ft} . \ldots \ldots \ldots \ldots \ldots \ldots \ldots$

4 to $5 \mathrm{ft} . \ldots \ldots \ldots \ldots \ldots \ldots \ldots$

melanocarpa (nigra)

2 to $3 \mathrm{ft} . \ldots \ldots \ldots \ldots \ldots \ldots \ldots$

3 to $4 \mathrm{ft} . \ldots \ldots \ldots \ldots \ldots \ldots \ldots$

AZALEA arborescens

15 to 18 in. $\mathrm{B} \& \mathrm{~B}$

18 to 24 in. $\mathrm{B} \& \mathrm{~B} \ldots \ldots \ldots \ldots \ldots \ldots$

2 to $21 / 2 \mathrm{ft} . \mathrm{B} \& \mathrm{~B} \ldots \ldots \ldots \ldots \ldots$

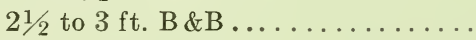
calendulacea (lutea)

15 to 18 in. $\mathrm{B} \& \mathrm{~B}$.

Red Chokeberry

$350 \quad 2500$

$\begin{array}{lllll}50 & 400 & 30 & 00\end{array}$

$\begin{array}{llll}60 & 500 \quad 4000\end{array}$

Black Chokeberry

$350 \quad 3000$

$50 \quad 400$

Fragrant Azalea

$150 \quad 1350 \quad 12000$

$\begin{array}{llllll}2 & 00 & 18 & 00 & 160 & 00\end{array}$

$250 \quad 22 \quad 50 \quad 20000$

$\begin{array}{llllll}3 & 00 & 28 & 00 & 260 & 00\end{array}$

Flame Azalea

$200 \quad 1800$

$250 \quad 2250$

$\begin{array}{llll}300 & 2800\end{array}$

500

Rhodora

$100 \quad 900$

$\begin{array}{llllrr}1 & 25 & 10 & 00 & 90 & 00\end{array}$

$\begin{array}{llllll}175 & 16 & 00 & 140 & 00\end{array}$

Gray Azalea

200

250 
mollis

15 to 18 in. $\mathrm{B} \& \mathrm{~B}$.

18 to 24 in. $B \& B \ldots \ldots \ldots \ldots \ldots$

2 to $2 \frac{1}{2} \mathrm{ft}$. B \&B

nudiflora

15 to 18 in. $\mathrm{B} \& \mathrm{~B}$

18 to 24 in. $\mathrm{B} \& \mathrm{~B}$

2 to $2 \frac{1}{2} \mathrm{ft}$. B \&B

pontica hybrida

Bouquet de Flora - pink

Daviesi - white

William III - orange

18 to 24 in. B \& B............. 250

2 to $2 \frac{1}{2} \mathrm{ft} . \mathrm{B} \& \mathrm{~B} \ldots \ldots \ldots \ldots \ldots \ldots \ldots . \ldots . \ldots 25$

poukhanense fl. pl. (Yodogawa)

18 to 24 in. B \&B.............

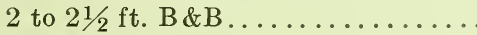

vaseyii

12 to 15 in. $B \& B$

15 to 18 in. $\mathrm{B} \& \mathrm{~B}$

18 to 24 in. $B \& B$

viscosa

18 to 24 in. B \&B.............

2 to $2 \frac{1}{2} \mathrm{ft}$. $\mathrm{B} \& \mathrm{~B} \ldots \ldots \ldots \ldots \ldots \ldots$

$21 / 2$ to $3 \mathrm{ft} . \mathrm{B} \& \mathrm{~B} \ldots \ldots \ldots \ldots \ldots \ldots$

3 to $4 \mathrm{ft} . \mathrm{B} \& \mathrm{~B} \ldots \ldots \ldots \ldots \ldots \ldots$

4 to $5 \mathrm{ft} . \mathrm{B} \& \mathrm{~B}$

BACCHARIS halimifolia

3 to $4 \mathrm{ft} . . \ldots \ldots \ldots \ldots \ldots \ldots \ldots$

4 to $5 \mathrm{ft} . \ldots \ldots \ldots \ldots \ldots \ldots \ldots$

\section{BERBERIS sieboldi}

2 to $21 / 2 \mathrm{ft} . \ldots \ldots \ldots \ldots \ldots \ldots \ldots$

$21 / 2$ to $3 \mathrm{ft} . \ldots \ldots \ldots \ldots \ldots \ldots \ldots$

3 to $4 \mathrm{ft} . \ldots \ldots \ldots \ldots \ldots \ldots \ldots$

thunbergii

18 to 24 in. bushy

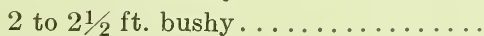

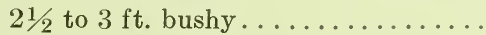

3 to $3 \frac{1}{2} \mathrm{ft}$. bushy.............

vulgaris

2 to $3 \mathrm{ft} . \ldots \ldots \ldots \ldots \ldots \ldots \ldots$. . . . . .

vulg. purpurea

2 to $3 \mathrm{ft} . \ldots \ldots \ldots \ldots \ldots \ldots \ldots$

3 to $4 \mathrm{ft} . \ldots \ldots \ldots \ldots \ldots \ldots \ldots$
Each Per 10 Per 100

Japanese Azalea

$\begin{array}{llllll}125 & 10 & 00 & 8500\end{array}$

$\begin{array}{llllll}175 & 16 & 00 & 140 & 00\end{array}$

225

Pinxter Flower

150

200

250

Hybrid Ghent Azalea

Double Korean Azalea

275

350

Southern Azalea

$150 \quad 1350$

$\begin{array}{llll}200 & 18 & 00\end{array}$

$250 \quad 2200$

Swamp Honeysuckle

$\begin{array}{llllll}200 & 1800 & 140 & 00\end{array}$

$\begin{array}{llllll}250 & 22 & 00 & 200 & 00\end{array}$

$\begin{array}{llllll}300 & 28 & 00 & 260 & 00\end{array}$

$\begin{array}{llllll}400 & 36 & 00 & 320 & 00\end{array}$

500

Groundsel Bush

$50 \quad 400$

$60 \quad 500$

Siebold's Barberry

$300 \quad 2000$

$350 \quad 2400$

$\begin{array}{llll}50 & 400 & 300 & 00\end{array}$

Japanese Barberry

$40 \quad 300 \quad 1800$

$\begin{array}{lllll}50 & 400 & 2500\end{array}$

$\begin{array}{lllll}60 & 5 & 00 & 40 & 00\end{array}$

$\begin{array}{llll}75 & 600 & 50 & 00\end{array}$

Common Barberry

$360 \quad 2400$

Purple Barberry

$\begin{array}{llll}3 & 50 & 24 & 00\end{array}$

$50 \quad 400$ 
BUDDLEIA variabilis magnifica

4 yrs......................

CALYCANTHUS floridus

18 to 24 in.

2 to $3 \mathrm{ft}$.

3 to $4 \mathrm{ft}$.

CEANOTHUS americanus

18 to 24 in.

2 to $21 / 2 \mathrm{ft}$.

CEPHALANTHUS occidentalis

2 to $3 \mathrm{ft} . \ldots \ldots \ldots \ldots \ldots \ldots$.

3 to $4 \mathrm{ft} . \ldots \ldots \ldots \ldots \ldots \ldots$.

CHIONANTHUS virginica - see under Trees

CLETHRA alnifolia

2 to $3 \mathrm{ft}$.

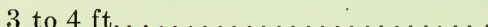

- 4 to $5 \mathrm{ft} . \ldots \ldots \ldots \ldots \ldots \ldots . . . . . .$.

COMPTONIA asplenifolia

2 to $3 \mathrm{ft} . . \ldots \ldots \ldots \ldots \ldots . . . . . .$.

CORNUS alternifolia

3 to $4 \mathrm{ft}$.

4 to $5 \mathrm{ft}$.

baileyi

3 to $4 \mathrm{ft}$.

kousa

2 to $3 \mathrm{ft}$

3 to $4 \mathrm{ft}$.

mascula

2 to $3 \mathrm{ft} . \ldots \ldots \ldots \ldots \ldots \ldots \ldots$

3 to $4 \mathrm{ft} . \ldots \ldots \ldots \ldots \ldots \ldots \ldots \ldots$

4 to $5 \mathrm{ft} . \ldots \ldots \ldots \ldots \ldots \ldots \ldots$

5 to $6 \mathrm{ft} . \ldots \ldots \ldots \ldots \ldots \ldots$

paniculata

2 to $3 \mathrm{ft}$

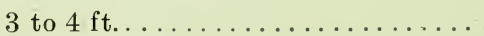

4 to $5 \mathrm{ft} . \ldots \ldots \ldots \ldots \ldots \ldots \ldots$

5 to $6 \mathrm{ft} . \ldots \ldots \ldots \ldots \ldots \ldots \ldots$

sanguinea

3 to $4 \mathrm{ft} . \ldots \ldots \ldots \ldots \ldots \ldots$

sericea

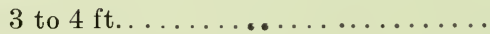

4 to $5 \mathrm{ft} . \ldots \ldots \ldots \ldots \ldots . . . . . . .$.

5 to $6 \mathrm{ft}$.
Each Per 10 Per 100

Butterfly Bush 60

Allspice

$50 \quad 350$

$60 \quad 4 \quad 00$

75

New Jersey Tea

$60 \quad 500$

75

$\begin{array}{lrrrr}\text { Button } & \text { Bush } & & \\ & 3 & 00 & 20 & 00 \\ 50 & 4 & 00 & \end{array}$

Sweet Pepper Bush

50 4. 00

$\begin{array}{lllll}60 & 5 & 00 & 40 & 00\end{array}$

$\begin{array}{lllll}75 & 6 & 00 & 4500\end{array}$

Sweet Fern

$60 \quad 500$

Blue Dogwood

$\begin{array}{lllll}50 & 4 & 00 & 30 & 00\end{array}$

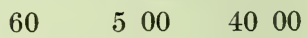

Bailey's Dogwood

$\begin{array}{lllll}50 & 400 & 30 & 00\end{array}$

Japanese Dogwood

$50 \quad 4 \quad 00$

$60 \quad 500$

Cornelian Cherry

\begin{tabular}{|c|c|}
\hline 350 & 25 \\
\hline 400 & 30 \\
\hline 500 & 40 \\
\hline 600 & \\
\hline
\end{tabular}

Gray Dogwood

$\begin{array}{lll}350 & 2500\end{array}$

$\begin{array}{lllll}50 & 4 & 00 & 30 & 00\end{array}$

$\begin{array}{lllll}60 & 5 & 00 & 40 & 00\end{array}$

$\begin{array}{lll}75 & 6 & 00\end{array}$

Red Osier

$50 \quad 400$

Silky Cornel

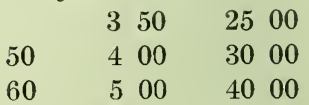


CORNUS-continued

siberica (alba)

4 to $5 \mathrm{ft}$.

5 to $6 \mathrm{ft}$

6 to $7 \mathrm{ft}$

sib. elegantissima

3 to $4 \mathrm{ft}$. .

sib. spaethi aurea

3 to $4 \mathrm{ft}$.

stolonifera lutea (aurea)

2 to $3 \mathrm{ft}$.

3 to $4 \mathrm{ft} . \ldots \ldots \ldots \ldots \ldots \ldots$

CORYLUS avellana aurea

7 to $8 \mathrm{ft}$.

COTONEASTER simonsii

2 to $3 \mathrm{ft} . \ldots \ldots \ldots \ldots \ldots \ldots$

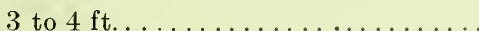

4 to $5 \mathrm{ft}$.

CYDONIA japonica

18 to 24 in...................

2 to $3 \mathrm{ft} . \ldots \ldots \ldots \ldots \ldots \ldots \ldots$

3 to $4 \mathrm{ft}$

jap. maulei

18 to 24 in................... .

2 to $3 \mathrm{ft} . \ldots \ldots \ldots \ldots \ldots \ldots \ldots$

jap. umbilicata

2 to $3 \mathrm{ft} . \ldots \ldots \ldots \ldots \ldots \ldots \ldots$

3 to $4 \mathrm{ft}$.

\section{DEUTZIA candidissima}

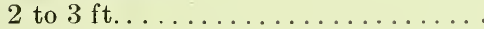

3 to $4 \mathrm{ft} . \ldots \ldots \ldots \ldots \ldots \ldots \ldots$

crenata

2 to $3 \mathrm{ft}$.

3 to $4 \mathrm{ft}$

4 to $5 \mathrm{ft}$.

cren. Pride of Rochester

3 to $4 \mathrm{ft}$.

4 to $5 \mathrm{ft}$.

gracilis

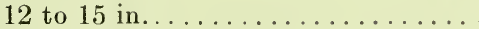

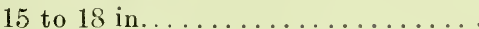

18 to 24 in.
Each Per 10 Per 100

Siberian or Red-barked Dogwood

$50 \quad 400 \quad 3000$

$\begin{array}{lllll}60 & 5 & 00 & 40 & 00\end{array}$

$\begin{array}{llll}75 & 600 & 5000\end{array}$

Silver Variegated Dogwood $60 \quad 500$

Golden Variegated Dogwood $75 \quad 600$

Yellow-barked Dogwood $50 \quad 400 \quad 3000$

$\begin{array}{lllll}60 & 500 & 40 & 00\end{array}$

Golden Hazel

$\begin{array}{lllll}75 & 6 & 00 & 50 & 00\end{array}$

Simons' Rose Box

$50 \quad 400$

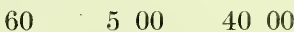

$\begin{array}{lll}75 & 6 & 00\end{array}$

Japanese Quince

300

$50 \quad 3 \quad 50$

$60 \quad 450$

Maule's Japanese Quince $50 \quad 400$

$60 \quad 500$

Red Japanese Quince

$\begin{array}{lllll}60 & 500 & 40 & 00\end{array}$ $\begin{array}{lllll}75 & 6 & 00 & 50 & 00\end{array}$

Double White Deutzia

350

$50 \quad 400$

Single White Deutzia

$350 \quad 2400$

$50 \quad 400 \quad 3000$

$\begin{array}{lllll}60 & 5 & 00 & 40 & 00\end{array}$

Pink Deutzia

$\begin{array}{lllll}50 & 4 & 00 & 30 & 00\end{array}$

$\begin{array}{lll}60 & 5 & 00\end{array}$

Dwarf Deutzia

$\begin{array}{llll}3 & 00 & 2200\end{array}$

$350 \quad 2800$

$\begin{array}{llll}50 & 400 & 3200\end{array}$ 
DEUTZIA-continued

grac. rosea

18 to 24 in

lemoinii

18 to 24 in:...................

2 to $3 \mathrm{ft} . \ldots \ldots \ldots \ldots \ldots \ldots \ldots$

watererii

3 to $4 \mathrm{ft}$.

4 to $5 \mathrm{ft}$

DIERVILLA candida

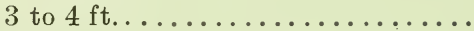

floribunda

3 to $4 \mathrm{ft} . \ldots \ldots \ldots \ldots \ldots \ldots . . . \ldots$.

hybrida Eva Rathke

18 to $24 \mathrm{in}$.

rosea

2 to $3 \mathrm{ft}$

3 to $4 \mathrm{ft}$

rosea variegata

18 to 24 in....................

\section{ELEAGNUS longipes}

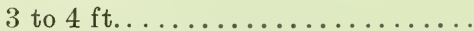

EUONYMUS alata

2 to $3 \mathrm{ft}$

3 to $4 \mathrm{ft}$

4 to $5 \mathrm{ft}$

5 to $6 \mathrm{ft}$.

6 to $8 \mathrm{ft}$. extra bushy Specimens..... americana

2 to $3 \mathrm{ft}$

3 to $4 \mathrm{ft}$

4 to $5 \mathrm{ft}$

bungeana

3 to $4 \mathrm{ft} . \ldots \ldots \ldots \ldots \ldots \ldots \ldots$

6 to $8 \mathrm{ft} . \ldots \ldots \ldots \ldots \ldots \ldots$

europaea

2 to $3 \mathrm{ft}$

3 to $4 \mathrm{ft} . \ldots \ldots \ldots \ldots \ldots \ldots \ldots$

4 to $5 \mathrm{ft}$.

EXOCHORDA grandiflora

3 to $4 \mathrm{ft} \ldots \ldots \ldots \ldots \ldots \ldots \ldots \ldots$

4 to $5 \mathrm{ft} \ldots \ldots \ldots \ldots \ldots \ldots \ldots \ldots$

5 to $6 \mathrm{ft} . \ldots \ldots \ldots \ldots \ldots \ldots \ldots$
Each Per 10 Per 100

Pink Dwarf Deutzia

$50 \quad 400 \quad 2800$

Lemoines Deutzia

$\begin{array}{lllll} & 3 & 00 & 2200 \\ 50 & 4 & 00 & 28 & 00\end{array}$

Waterer's Deutzia

$50 \quad 400$

$60 \quad 500$

White Weigela

ј0

Red Weigela

50

Carmine Weigela $50 \quad .400 \quad 3000$

Pink Weigela

$\begin{array}{lllll} & 3 & 50 & 25 & 00 \\ 50 & 4 & 00 & 30 & 00\end{array}$

Variegated Weigela $350 \quad 2500$

Japanese Oleaster 60

Burning Bush

$80 \quad 650$

$\begin{array}{llllll}1 & 00 & 8 & 00 & 60 & 00\end{array}$

$\begin{array}{llllll}1 & 75 & 15 & 00 & 140 & 00\end{array}$

$300 \quad 2800$

$\begin{array}{llllll}5 & 00 & 45 & 00 & 400 & 00\end{array}$

American Spindle Tree

$60 \quad 500$

$\begin{array}{lll}80 & 7 & 00\end{array}$

$100 \quad 900$

Pink-fruited Spindle Tree $80 \quad 700$

$150 \quad 1200$

Spindle Tree 60

$75 \quad 600$

$100 \quad 800$

Pearl Bush

$50 \quad 4 \quad 00 \quad 3000$

$\begin{array}{lllll}60 & 5 & 00 & 40 & 00\end{array}$

$\begin{array}{lllll}75 & 600 \quad 5000\end{array}$

$100 \quad 800$ 
FORSYTHIA fortuneii

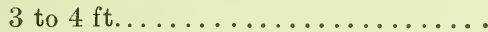

4 to $5 \mathrm{ft} . \ldots \ldots \ldots \ldots \ldots \ldots \ldots$.

5 to $6 \mathrm{ft} . \ldots \ldots \ldots \ldots \ldots \ldots \ldots$

intermedia

3 to $4 \mathrm{ft}$.

suspensa

3 to $4 \mathrm{ft} . \ldots \ldots \ldots \ldots \ldots \ldots \ldots$

4 to $5 \mathrm{ft} . \ldots \ldots \ldots \ldots \ldots \ldots \ldots$

viridissima

3 to $4 \mathrm{ft} . \ldots \ldots \ldots \ldots \ldots \ldots$. . . . . .

GENISTA tinctoria

2 to $3 \mathrm{ft}$.

HAMMELIS virginica

2 to $3 \mathrm{ft}$.

3 to $4 \mathrm{ft}$.

HIPPOPHAE rhamnoides

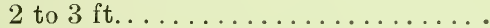

3 to $4 \mathrm{ft} . \ldots \ldots \ldots \ldots \ldots \ldots \ldots$

4 to $5 \mathrm{ft} . \ldots \ldots \ldots \ldots \ldots \ldots \ldots$

HYDRANGEA arborescens sterilis

2 to $3 \mathrm{ft} . \ldots \ldots \ldots \ldots \ldots \ldots$

3 to $4 \mathrm{ft} . \ldots \ldots \ldots \ldots \ldots \ldots \ldots$

bretschneideri (vestita)

3 to $4 \mathrm{ft} . \ldots \ldots \ldots \ldots \ldots \ldots$.

paniculata (type)

3 to $4 \mathrm{ft}$. .

paniculata grandiflora

2 to $3 \mathrm{ft}$

3 to $4 \mathrm{ft} . \ldots \ldots \ldots \ldots \ldots \ldots \ldots$

pan. grand. tree form

2 to $3 \mathrm{ft} . \ldots \ldots \ldots \ldots \ldots \ldots$.

radiata

3 to $4 \mathrm{ft}$.

HYPERICUM kalmianum

18 to 24 in

ILEX verticilata

2 to $3 \mathrm{ft}$.

3 to $4 \mathrm{ft}$.

4 to $5 \mathrm{ft}$.

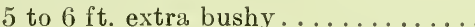

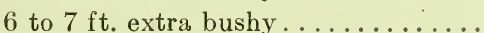

Each Per 10 Per 100 Fortune's Golden Bell

$\begin{array}{lllll}50 & 300 & 2400\end{array}$

$\begin{array}{lllll}60 & 4 & 00 & 30 & 00\end{array}$

$\begin{array}{lllll}75 & 5 & 00 & 40 & 00\end{array}$

Golden Bell

50

Drooping Golden Bell

$50 \quad 300$

$\begin{array}{lllll}60 & 4 & 00 & 30 & 00\end{array}$

Green-twigged Golden Bell $\begin{array}{lllll}50 & 300 & 2400\end{array}$

Greenweed

$\begin{array}{lllll}50 & 400 & 30 & 00\end{array}$

Witch Hazel

$60 \quad 500$

$75 \quad 600$

Sea Buckthorn

$\begin{array}{lllll}50 & 400 & 30 & 00\end{array}$

$\begin{array}{lllll}60 & 5 & 00 & 40 & 00\end{array}$

$\begin{array}{lllll}75 & 6 & 00 & 45 & 00\end{array}$

Snowball Hydrangea

$50 \quad 400 \quad 3200$

$\begin{array}{lllll}60 & 5 & 00 & 40 & 00\end{array}$

Red-twigged Hydrangea $50 \quad 400$

Panicled Hydrangea $60 \quad 500$

Common Hydrangea

$\begin{array}{lllll}50 & 4 & 00 & 30 & 00\end{array}$

$\begin{array}{llll}60 & 500 \quad 4000\end{array}$

Tree Hydrangea

75

Silvery Hydrangea

$\begin{array}{lllll}50 & 400 \quad 30 & 00\end{array}$

St. John's Wort

350

Winterberry or Black Alder

\begin{tabular}{|c|c|c|}
\hline 60 & 500 & 36 \\
\hline 75 & 600 & 50 \\
\hline 00 & 850 & 70 \\
\hline 50 & 1200 & 100 \\
\hline 00 & 1800 & 150 \\
\hline
\end{tabular}


KERRIA japonica

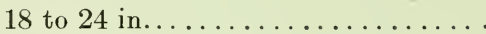

2 to $2 \frac{1}{2} \mathrm{ft} \ldots \ldots \ldots \ldots \ldots \ldots$

jap. variegata

18 to 24 in

$21 / 2$ to $3 \mathrm{ft}$.

\section{LIGUSTRUM amurense}

2 to $3 \mathrm{ft} . \ldots \ldots \ldots \ldots \ldots \ldots \ldots$

3 to $4 \mathrm{ft} \ldots \ldots \ldots \ldots \ldots \ldots \ldots$

4 to $5 \mathrm{ft} . \ldots \ldots \ldots \ldots \ldots \ldots \ldots \ldots$

ibota

2 to $3 \mathrm{ft}$

3 to $4 \mathrm{ft}$.

iobta regeleanum

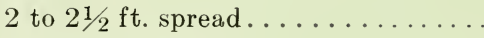

$21 / 2$ to $3 \mathrm{ft}$. spread..............

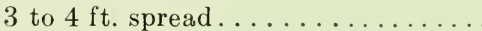

ovalifolium

2 to $3 \mathrm{ft} . \ldots \ldots \ldots \ldots \ldots \ldots$.

3 to $4 \mathrm{ft} . \ldots \ldots \ldots \ldots \ldots \ldots \ldots$

4 to $5 \mathrm{ft} . \ldots \ldots \ldots \ldots \ldots \ldots$

vulgare

2 to $3 \mathrm{ft}$.

3 to $4 \mathrm{ft}$.

LONICERA fragrantissima

2 to $3 \mathrm{ft} . \ldots \ldots \ldots \ldots \ldots \ldots$

3 to $4 \mathrm{ft} . \ldots \ldots \ldots \ldots \ldots \ldots \ldots$

morrowii - true spreading form

2 to $3 \mathrm{ft} . \ldots \ldots \ldots \ldots \ldots \ldots \ldots \ldots$

3 to $4 \mathrm{ft} \ldots \ldots$

morrowi - upright seedling form

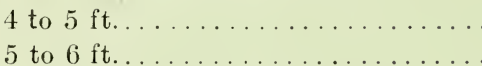

ruprechtiana

3 to $4 \mathrm{ft}$.

4 to $5 \mathrm{ft} \ldots \ldots \ldots \ldots \ldots \ldots \ldots \ldots$

5 to $6 \mathrm{ft} \ldots \ldots \ldots \ldots \ldots \ldots \ldots$

standishii

3 to $4 \mathrm{ft} . \ldots \ldots \ldots \ldots \ldots \ldots \ldots$

4 to $5 \mathrm{ft}$
Each Per 10 Per 100

Globe.Flower

$50 \quad 400$

3200

$60 \quad 500$

Variegated Globe Flower

60

450

$\begin{array}{lllll}75 & 6 & 00 & 42 & 00\end{array}$

A moor River Privet

$40 \quad 300 \quad 2000$

$\begin{array}{lllll}50 & 4 & 00 & 28 & 00\end{array}$

$60 \quad 500 \quad 3600$

Chinese Privet

$\begin{array}{llll} & 300 & 2000 \\ 50 & 360 & 28 & 00\end{array}$

Regel's Privet

$50 \quad 3 \quad 60 \quad 2800$

$\begin{array}{lllll}60 & 4 & 50 & 32 & 00\end{array}$

$\begin{array}{lllll}75 & 60 \mathrm{O} & 36 & 00\end{array}$

California Privet

$25 \quad 180 \quad 1000$

$30 \quad 220 \quad 1200$

$40 \quad 300 \quad 1600$

English Privet

$300 \quad 2000$

$50 \quad 400$

Fragrant Honeysuckle

$50 \quad 360 \quad 2400$

$\begin{array}{lllll}60 & 400 & 30 & 00\end{array}$

Japanese Bush.Honeysuckle

$50 \quad 400 \quad 3200$

$\begin{array}{lllll}60 & 5 & 00 & 40 & 00\end{array}$

$50 \quad 400 \quad 2800$

$\begin{array}{lllll}60 & 500 & 36 & 00\end{array}$

Ruprecht's Honeysuckle

$50 \quad 320 \quad 2400$

$\begin{array}{lllll}60 & 4 & 00 & 30 & 00\end{array}$

$\begin{array}{lllll}75 & 5 & 00 & 40 & 00\end{array}$

Standish's Honeysuckle $5 \mathrm{C} \quad 400 \quad 3000$

$\begin{array}{lllll}60 & 5 & 00 & 36 & 00\end{array}$ 
LONICERA—continued

tatarica

3 to $4 \mathrm{ft}$

4 to $5 \mathrm{ft}$.

tat. albida

3 to $4 \mathrm{ft}$.

tat. grandiflora alba

2 to $3 \mathrm{ft} . \ldots \ldots \ldots \ldots \ldots \ldots$

3 to $4 \mathrm{ft} . \ldots \ldots \ldots \ldots \ldots \ldots \ldots$

2 to $3 \mathrm{ft} . . . . \ldots \ldots \ldots \ldots \ldots \ldots$

3 to $4 \mathrm{ft} . \ldots \ldots \ldots \ldots \ldots \ldots \ldots$

4 to $5 \mathrm{ft}$

tat. grand. rubra

2 to $3 \mathrm{ft} . \ldots \ldots \ldots \ldots \ldots \ldots \ldots$

3 to $4 \mathrm{ft} . \ldots \ldots \ldots \ldots \ldots \ldots$

\section{MYRICA cerifera}

12 to 15 in.

15 to 18 in

18 to 24 in.

2 to $3 \mathrm{ft}$., extra bushy

gale

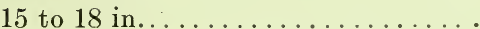

\section{PHILADEPLHUS coronarius}

3 to $4 \mathrm{ft} . \ldots \ldots \ldots \ldots \ldots \ldots \ldots$

4 to $5 \mathrm{ft} . \ldots \ldots \ldots \ldots \ldots \ldots \ldots \ldots$

5 to $6 \mathrm{ft} . \ldots \ldots \ldots \ldots \ldots \ldots \ldots$

$6 \mathrm{t}$ ว $8 \mathrm{ft} . \ldots \ldots \ldots \ldots \ldots \ldots \ldots \ldots$

cor. aureus

15 to 18 in

18 to 24 in

cor. nanus

18 to 24 in....................

grandiflorus

3 to $4 \mathrm{ft} . \ldots \ldots \ldots \ldots \ldots \ldots \ldots$

4 to $5 \mathrm{ft} . \ldots \ldots \ldots \ldots \ldots \ldots \ldots$.

5 to $6 \mathrm{ft} . \ldots \ldots \ldots \ldots \ldots \ldots \ldots$

lemoinei

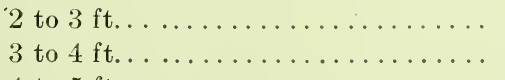

tat. grand. rosea

Each Per 10 Per 100

Tatarian Honeysuckle

$50 \quad 400 \quad 3000$

$\begin{array}{lllll}60 & 500 & 40 & 00\end{array}$

Yellow Bush Honeysuckle

$50 \quad 400 \quad 3000$

White Tatarian Honeysuckle

$350 \quad 2500$

$\begin{array}{lllll}50 & 400 & 30 & 00\end{array}$

Large-flowered Honeysuckle

\begin{tabular}{|c|c|}
\hline & 350 \\
\hline & 400 \\
\hline & 500 \\
\hline
\end{tabular}

Red Tatarian Honeysuckle $350 \quad 2500$ $\begin{array}{lllll}50 & 4 & 00 & 30 & 00\end{array}$

Candleberry

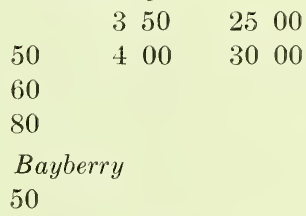

Syringa or Wock Orange $350 \quad 2500$ $50 \quad 400 \quad 3000$

$\begin{array}{lllll}60 & 5 & 00 & 36 & 00\end{array}$

$\begin{array}{lllll}80 & 6 & 00 & 45 & 00\end{array}$

Golden Syringa

$50 \quad 400$

$60 \quad 500$

Dwarf Mock Orange $50 \quad 400$

Large-flowered Syringa $300 \quad 2000$ $\begin{array}{lllll}50 & 4 & 00 & 28 & 00\end{array}$

$\begin{array}{lllll}60 & 5 & 00 & 36 & 00\end{array}$

Lemoine's Mock Orange $50 \quad 360$

$\begin{array}{lllll}60 & 4 & 50 & 3200\end{array}$

$\begin{array}{lllll}75 & 6 & 00 & 40 & 00\end{array}$

lemoinei hybrida

Lemoine's Hybrid Mock Oranges

AVALANCHE

2 to $3 \mathrm{ft}$.

3 to $4 \mathrm{ft}$. 
PHILADELPHUS-continued

Each Per 10 Per 100

BOUQUET DE BLANC - Especially Fine

2 to $3 \mathrm{ft} . \ldots \ldots \ldots \ldots \ldots \ldots \ldots \ldots$

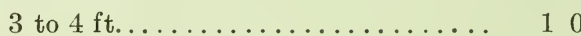

$\begin{array}{lllll}75 & 650 & 50 & 00\end{array}$

CONQUETTE

2 to $3 \mathrm{ft}$.

50

$400 \quad 3000$

DAME BLANCHE

2 to $3 \mathrm{ft}$

50

$400 \quad 3000$

ERECTUS

2 to $3 \mathrm{ft} . \ldots \ldots \ldots \ldots \ldots \ldots$

3 to $4 \mathrm{ft} . . \ldots \ldots \ldots \ldots \ldots \ldots$

\section{MONT BLANC}

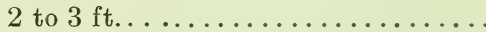

3 to $4 \mathrm{ft}$.

60

MULTIFLORUS PLENUS

2 to $3 \mathrm{ft} . \ldots \ldots \ldots \ldots \ldots \ldots$

3 to $4 \mathrm{ft} . \ldots \ldots \ldots \ldots \ldots \ldots$

PRUNUS japonica alba plena

3 to $4 \mathrm{ft}$.

50

60

$360 \quad 2400$

$\begin{array}{lllll}60 & 450 & 32 & 00\end{array}$

$50 \quad 360 \quad 2400$

$\begin{array}{lllll}60 & 450 & 32 & 00\end{array}$

$50 \quad 400 \quad 300_{0}$

$\begin{array}{lllll}60 & 450 & 35 & 0\end{array}$

Double White Almond $60 \quad 500$

jap. rosea plena

2 to $3 \mathrm{ft} . \ldots \ldots \ldots \ldots \ldots \ldots$

Double Pink Almond

3 to $4 \mathrm{ft} \ldots \ldots \ldots \ldots \ldots \ldots \ldots \ldots$

maritima

3 to $4 \mathrm{ft} . \ldots \ldots \ldots \ldots \ldots \ldots \ldots$

tomentosa

4 to $5 \mathrm{ft} . . . \ldots \ldots \ldots \ldots \ldots \ldots . . . .$.

5 to $6 \mathrm{ft} . \ldots \ldots \ldots \ldots \ldots \ldots \ldots$

triloba

2 to $3 \mathrm{ft}$

3 to $4 \mathrm{ft}$. 50

Beach Plum

$60 \quad 400$ 3200

$75 \quad 600$

Chinese Cjherry

50

60

Flowering Almond

$50 \quad 400$

60

PYRUS - see ARONIA

RHAMNUS caroliniana (frangula)

4 to $5 \mathrm{ft}$.

Carolina Buckthorn

5 to $6 \mathrm{ft}$.

50

400

3000

$60 \quad 4 \quad 50$

3500

6 to $7 \mathrm{ft}$

75

500

4000

catharticus

4 to $5 \mathrm{ft} . \ldots \ldots \ldots \ldots \ldots \ldots \ldots$

5 to $6 \mathrm{ft} . \ldots \ldots \ldots \ldots \ldots \ldots \ldots$

60

Buckthorn

$75 \quad 600$

RHODORA - see AZALEA canadensis

RHODOTYPIUS kerrioides

2 to $3 \mathrm{ft} . \ldots \ldots \ldots \ldots \ldots \ldots \ldots$

White Kerria

3 to $4 \mathrm{ft} . \ldots \ldots \ldots \ldots \ldots \ldots \ldots \ldots$ 


\section{RHUS aromatica}

2 to $3 \mathrm{ft} . . \ldots \ldots \ldots \ldots \ldots \ldots \ldots$

3 to $4 \mathrm{ft} . \ldots \ldots \ldots \ldots \ldots \ldots . \ldots . \ldots$

cotinus

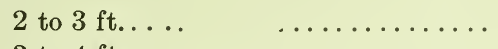

3 to $4 \mathrm{ft} . \ldots \ldots \ldots \ldots \ldots \ldots \ldots$

4 to $5 \mathrm{ft} . \ldots \ldots \ldots \ldots \ldots \ldots \ldots$

5 to $6 \mathrm{ft} . \ldots \ldots \ldots \ldots \ldots \ldots \ldots$

glabra

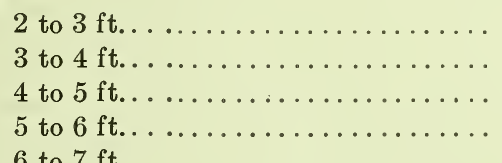

typhina

3 to $4 \mathrm{ft} . \ldots \ldots \ldots \ldots \ldots \ldots \ldots$

5 to $6 \mathrm{ft} . \ldots \ldots \ldots \ldots \ldots \ldots \ldots$

6 to $8 \mathrm{ft} . \ldots \ldots \ldots \ldots \ldots \ldots \ldots$

ROSA blanda

2 to $3 \mathrm{ft} . . . \ldots \ldots \ldots \ldots \ldots$

carolina

3 to $4 \mathrm{ft} . \ldots \ldots \ldots \ldots \ldots \ldots$

lucida

2 to $3 \mathrm{ft} . \ldots \ldots \ldots \ldots \ldots \ldots$

multiflora

3 to $4 \mathrm{ft} . . \ldots \ldots \ldots \ldots \ldots$

nitida

2 to $3 \mathrm{ft}$.

rubiginosa

3 to $4 \mathrm{ft} . . . \ldots \ldots \ldots \ldots \ldots \ldots . . \ldots$

rubrifolia

18 to 24 in.

2 to $3 \mathrm{ft}$.

rugosa

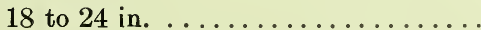

3 to $3 \mathrm{ft} . . . \ldots \ldots \ldots \ldots \ldots \ldots$

rugosa alba

2 to $3 \mathrm{ft} . . \ldots \ldots \ldots \ldots \ldots \ldots$

setigera

3 to $4 \mathrm{ft} . \ldots \ldots \ldots \ldots \ldots \ldots$

wichuraiana

4 yrs.
Each Per 10 Per 100

Fragrant Sumac

$50 \quad 400 \quad 3000$

$\begin{array}{lllll}60 & 500 & 40 & 00\end{array}$

Smoke Bush

$350 \quad 2400$

$\begin{array}{lllll}50 & 400 & 30 & 00\end{array}$

$\begin{array}{lllll}60 & 500 & 40 & 00\end{array}$

$100 \quad 800$

Smooth Sumac

$250 \quad 2500$

$\begin{array}{lllll}50 & 4 & 00 & 30 & 00\end{array}$

$60 \quad 500$

75

100

Staghorn Sumac 50

75

100

Meadow Rose

$300 \quad 2000$

Swamp Rose

$300 \quad 2000$

Wild Rose

$50 \quad 400 \quad 3000$

Japanese Climbing Rose $\begin{array}{lll}50 & 400 & 2500\end{array}$

Shiny-leaved Rose

$\begin{array}{lllll}50 & 400 & 28 & 00\end{array}$

Sweet Briar Rose

$\begin{array}{lllll}50 & 400 & 30 & 00\end{array}$

Red-leaved Rose

$300 \quad 2000$

$\begin{array}{lllll}50 & 400 & 30 & 00\end{array}$

Japanese Rose

$\begin{array}{lllll}50 & 4 & 00 & 30 & 00\end{array}$

$60 \quad 500$

White Japanese Rose

$\begin{array}{llll}50 & 400 & 30 & 00\end{array}$

Prairie Rose

$50 \quad 350$

Memorial Rose

75 


\section{SAMBUCUS canadensis}

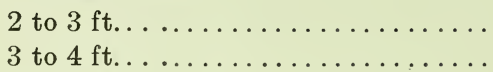

nigra aurea

2 to $3 \mathrm{ft} . \ldots \ldots \ldots \ldots \ldots \ldots \ldots$

3 to $4 \mathrm{ft} . \ldots \ldots \ldots \ldots \ldots \ldots \ldots$

racemosus (pubens)

3 to $4 \mathrm{ft} . \ldots \ldots \ldots \ldots \ldots \ldots \ldots$. . . . . . .

4 to $5 \mathrm{ft} . \ldots \ldots \ldots \ldots \ldots \ldots \ldots$

SORBARIA arborea

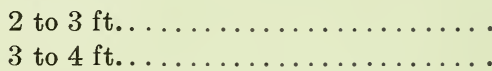

SPIRAEA arguta

2 to $3 \mathrm{ft}$. bushy

blumei

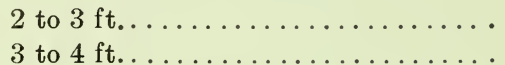
bumalda

18 to 24 in...................

2 to $3 \mathrm{ft} . \ldots \ldots \ldots \ldots \ldots \ldots$.

bum. Anthony Waterer

18 to 24 in

2 to $3 \mathrm{ft}$.

callosa alba

18 to 24 in

opulifolia

4 to $5 \mathrm{ft} . \ldots \ldots \ldots \ldots \ldots \ldots \ldots$

5 to $6 \mathrm{ft}$.

opul. aurea

4 to $5 \mathrm{ft} . \ldots \ldots \ldots \ldots \ldots \ldots \ldots$

5 to $6 \mathrm{ft} . \ldots \ldots \ldots \ldots \ldots \ldots \ldots$

prunifolia fl. pl.

3 to $4 \mathrm{ft} . \ldots \ldots \ldots \ldots \ldots \ldots \ldots$

reevesi

2 to $3 \mathrm{ft} . \ldots \ldots \ldots \ldots \ldots \ldots \ldots$

saticifolia

3 to $4 \mathrm{ft} . \ldots \ldots \ldots \ldots \ldots \ldots \ldots$

4 to $5 \mathrm{ft} . \ldots \ldots \ldots \ldots \ldots \ldots \ldots$.

sorbifolia - see SORBARIA

thunbergii

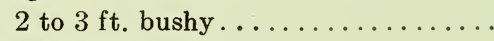

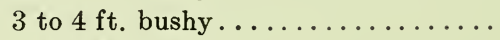

4 to $5 \mathrm{ft}$. bushy
Each Per 10 Per 100

Elderberry

$50 \quad 350$

2500

$60 \quad 450$

Golden Elder

$50 \quad 350$

$\begin{array}{lllll}60 & 450 & 36 & 00\end{array}$

Red-berried Elder

$50 \quad 400 \quad 3200$

$\begin{array}{llll}60 & 500 \quad 4000\end{array}$

Ash-leaved Spiraea

$50 \quad 400 \quad 3000$

$\begin{array}{lll}60 & 500 \quad 4000\end{array}$

Hybrid Snow Garland

$360 \quad 2800$

$50 \quad 400 \quad 3200$

Blume's Spiraea

$300 \quad 2000$

$\begin{array}{lll}50 & 400 & 3000\end{array}$

Pink Everblooming Spiraea

$50 \quad 300 \quad 2000$

$60 \quad 400 \quad 3000$

Crimson Everblooming Spiraea

$\begin{array}{lllll}50 & 320 & 24 & 00\end{array}$

$60 \quad 400 \quad 3200$

Fortune's White Spiraea $50 \quad 400$

Nine Bark

$\begin{array}{llll}50 & 400 & 30 & 00\end{array}$ $60 \quad 500 \quad 4000$

Golden Nine Bark

$50 \quad 400 \quad 3000$

$60 \quad 500 \quad 4000$

True Bridal Wreath

$75 \quad 650$

Reeve's Spiraea

$\begin{array}{lllll}50 & 400 & 30 & 00\end{array}$

Willow-leaved Spiraea

$50 \quad 400 \quad 2000$

$\begin{array}{lllll}60 & 500 & -3500\end{array}$

Snow Garland

$\begin{array}{rrrrr} & 320 & 24 & 00 \\ 50 & 400 & 30 & 00 \\ 60 & -4 & 50\end{array}$


SPIRAEA - continued

tomentosa

3 to $4 \mathrm{ft} . \ldots \ldots \ldots \ldots \ldots \ldots \ldots$

ulmifolia

4 to $5 \mathrm{ft} . . . \ldots \ldots \ldots \ldots \ldots \ldots \ldots$

vanhouttei

3 to $4 \mathrm{ft} . \ldots \ldots \ldots \ldots \ldots \ldots \ldots$

4 to $5 \mathrm{ft} . \ldots \ldots \ldots \ldots \ldots \ldots \ldots$

5 to $6 \mathrm{ft}$

STEPHANANDRA flexuosa

3 to $4 \mathrm{ft}$.

\section{SYMPHORICARPOS racemosus}

2 to $3 \mathrm{ft} . . \ldots \ldots \ldots \ldots \ldots \ldots \ldots$

3 to $4 \mathrm{ft} . \ldots \ldots \ldots \ldots \ldots \ldots \ldots$

vulgaris

2 to $3 \mathrm{ft} . \ldots \ldots \ldots \ldots \ldots \ldots \ldots$

3 to $4 \mathrm{ft}$.

\section{SYRINGA}

josikaea

2 to $3 \mathrm{ft}$.

3 to $4 \mathrm{ft}$.

4 to $5 \mathrm{ft}$.

persica

3 to $4 \mathrm{ft}$.

4 to $5 \mathrm{ft}$

persica alba

3 to $4 \mathrm{ft} . \ldots \ldots \ldots \ldots \ldots \ldots \ldots$

4 to $5 \mathrm{ft} . \ldots \ldots \ldots \ldots \ldots \ldots \ldots$

rothomagensis

2 to $3 \mathrm{ft} . . . \ldots \ldots \ldots \ldots \ldots . . . \ldots$

3 to $4 \mathrm{ft} . . \ldots \ldots \ldots \ldots \ldots \ldots \ldots$

4 to $5 \mathrm{ft}$.

vulgaris

3 to $4 \mathrm{ft}$.

4 to $5 \mathrm{ft}$.

5 to $6 \mathrm{ft}$.

vulgaris alba

3 to $4 \mathrm{ft} . \ldots \ldots \ldots \ldots \ldots \ldots \ldots$

4 to $5 \mathrm{ft} . \ldots \ldots \ldots \ldots \ldots \ldots \ldots$

5 to $6 \mathrm{ft} \ldots \ldots \ldots \ldots \ldots \ldots \ldots$

6 to $8 \mathrm{ft}$.
Each Per 10 Per 100

Hardhack

$\begin{array}{llll}50 & 400 & 3000\end{array}$

Elm-leaved Spiraea

$60 \quad 500$

Bridal Bower

$50 \quad 400$

2800

$\begin{array}{lllll}75 & 500 & 3600\end{array}$

$100 \quad 800$

\section{Lace Shrub}

$50 \quad 400 \quad 3000$

Snowberry

$\begin{array}{lllll} & 3 & 00 & 20 & 00 \\ 50 & 3 & 60 & 24 & 00\end{array}$

Coral Berry

$300 \quad 2000$
300

$\begin{array}{lllll}50 & 360 & 2400\end{array}$

Hungarian Lilac

$350 \quad 2500$

$50 \quad 400 \quad 3000$

$60 \quad 500 \quad 4000$

Persian Lilac

$\begin{array}{lllll}75 & 6 & 00 & 40 & 00\end{array}$

$100 \quad 800$

White Persian Lilac

$\begin{array}{lllll}75 & 6 & 00 & 40 & 00\end{array}$

$100 \quad 800$

Rouen Lilac

$60 \quad 500$

$\begin{array}{lllll}75 & 6 & 00 & 40 & 00\end{array}$

$100 \quad 800$

Common Lilac

$\begin{array}{lllll}60 & 5 & 00 & 36 & 00\end{array}$

$80 \quad 700 \quad 6000$

$125 \quad 1000$

Common White Lilac

$\begin{array}{lllll}60 & 5 & 00 & 36 & 00\end{array}$

$80 \quad 7 \quad 00 \quad 6000$

$\begin{array}{llllll}1 & 25 & 10 & 00 & 80 & 00\end{array}$

$200 \quad 1800 \quad 14000$ 


\section{HYBRID LILACS}

Named Varieties

CLASS A

The varieties in this list are the best sorts we have been able to obtain in either Europe or America. If we have not the size in stock of any variety ordered we shall select the sort most nearly approaching the desired variety UNLESS OTHERWISE SPECIFIED.

\begin{tabular}{|c|c|c|c|}
\hline & Each & Per 10 & Per 100 \\
\hline 2 to $3 \mathrm{ft} . .$. & 75 & 600 & 5000 \\
\hline 3 to $4 \mathrm{ft} . .$. & 100 & 800 & 6000 \\
\hline 4 to $5 \mathrm{ft} . . \ldots \ldots \ldots$ & 150 & 1250 & 10000 \\
\hline
\end{tabular}

ABEL CARRIERE-Double. Buds pink, opening bluish lilac.

ALPHONSE LAVELLE-Double. Large pannicles. Pale lavender.

CHARLES JOLY-Double deep red. Extra fine.

CHARLES $X$-Single. Reddish purple. Very free.

DOCTOR MAILLOT-Double. Light lavender, buds opening pale, blue; cry free.

DOYEN KETELER-Double. Pale pink lilac.

JEAN BART-Double. Early. Petals pointed. Bright reddish-purple bud openn pale reddish-purple.

JEANNE D'ARC-Double. White. Very free.

LUDWIG SPAETH-Single. Large. Wine-colored buds open dark red.

MARIE LEGRAY-Single. White. Free. Dwarf.

MICHAEL BUCHNER-Double. Free. Pink buds open pale bluish lilac MME. ABEL CHATENAY-Double. White.

MME. CASIMER PERIER-Double. Cream white.

MME. LEMOINE-Double. Large. White.

NEGRO-Single. Large. Deep red.

PRESIDENT CARNOT-Double, Long pannicles. Light purple buds open pale blue.

SENATEUR VOLLAND-Double. Free. Bright pink buds open delicate light pinkish-lilac.

WILLIAM ROBINSON-Double. Buds red, opening with outer petals reddish and inner petals bluish. Very fine. 


\section{HYBRID LILACS-Continued}

\section{CLASS B}

The varieties in this list are not so choice as those in CLASS A but are very desirable sorts, nevertheless. If we have not the size in stock of any variety ordered we shall select the sort most nearly approaching the desired variety UNLESS OTHERWISE SPECIFIED.

\begin{tabular}{|c|c|c|c|}
\hline & Each & Per 10 & Per 100 \\
\hline to $3 \mathrm{ft}$ & 70 & 550 & 4500 \\
\hline t. . & 90 & 750 & 5500 \\
\hline $5 \mathrm{ft}$. & 125 & 1000 & 8000 \\
\hline
\end{tabular}

BELLE DE NANCY—Double. Pink buds open bluish lavender. CHARLES BALTET—Single. Bluish purple.

CONDORCET-Double. Large. Pale blue.

CONGO—Single. Deep reddish purple, fading to pinkish purple.

BERTHA DAMMANN-Single. White.

DOCTOR LINDLEY — Single. Pinkish lilac.

LEON SIMON-Double. Lavender.

PRINZ NOTGER-Single. Pale Blue.

RUBRA DE MARLEY - Single. Rosy purple.

SANGUINEA RUBRA MAJOR-Single. Rosy lilac.

\section{MIXED VARIETIES}

Composed of sorts listed in CLASSES A and B from which the labels have been lost.

\begin{tabular}{|c|c|c|c|}
\hline & Each & Per 10 & Per 100 \\
\hline 2 to $3 \mathrm{ft}$. & 60 & 500 & \\
\hline 3 to $4 \mathrm{ft}$.. & 80 & 650 & 5000 \\
\hline 4 to $5 \mathrm{ft} \ldots \ldots \ldots \ldots$ & 100 & 900 & \\
\hline
\end{tabular}

TAMARIX africana

African T'amarisk

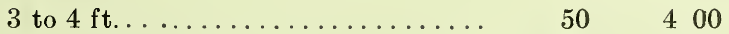

4 to $5 \mathrm{ft} \ldots \ldots \ldots \ldots \ldots \ldots \ldots \ldots$............ $60 \quad 500$

hispida aestivalis

Bristly Tamarisk

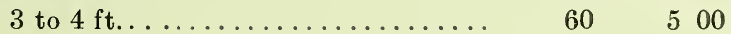

VACCINIUM corymbosum

High-bush Blueberry

18 to 24 in.................. 60

$\begin{array}{lllll}60 & 5 & 00 & 40 & 00\end{array}$

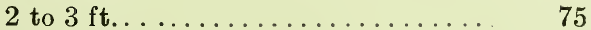

3 to $4 \mathrm{ft} . \ldots \ldots \ldots \ldots \ldots \ldots \ldots . \ldots \ldots$ 


\section{VIBURNUM acerifolium}

18 to 24 in.

2 to $3 \mathrm{ft}$.

cassinoides

2 to $3 \mathrm{ft} . \ldots \ldots \ldots \ldots \ldots \ldots \ldots \ldots$

3 to $4 \mathrm{ft} . \ldots \ldots \ldots \ldots \ldots \ldots \ldots$

dentatum

3 to $4 \mathrm{ft} . \ldots \ldots \ldots \ldots \ldots \ldots \ldots$

4 to $5 \mathrm{ft} . \ldots \ldots \ldots \ldots \ldots \ldots \ldots$

5 to $6 \mathrm{ft} . \ldots \ldots \ldots \ldots \ldots \ldots \ldots$

lantana

2 to $3 \mathrm{ft} . \ldots \ldots \ldots \ldots \ldots \ldots \ldots$

3 to $4 \mathrm{ft} . \ldots \ldots \ldots \ldots \ldots \ldots \ldots$

lentago

2 to $3 \mathrm{ft} . \ldots \ldots \ldots \ldots \ldots \ldots$

3 to $4 \mathrm{ft} . \ldots \ldots \ldots \ldots \ldots \ldots \ldots \ldots$

4 to $5 \mathrm{ft} . \ldots \ldots \ldots \ldots \ldots \ldots \ldots$

5 to $6 \mathrm{ft} . \ldots \ldots \ldots \ldots \ldots \ldots \ldots$

6 to $7 \mathrm{ft}$.

opulus

3 to $4 \mathrm{ft} . \ldots \ldots \ldots \ldots \ldots \ldots \ldots$

4 to $5 \mathrm{ft} . \ldots \ldots \ldots \ldots \ldots \ldots \ldots \ldots$

5 to $6 \mathrm{ft} . \ldots \ldots \ldots \ldots \ldots \ldots \ldots$

6 to $8 \mathrm{ft} . \ldots \ldots \ldots \ldots \ldots \ldots$

op. sterilis

2 to $3 \mathrm{ft} . \ldots \ldots \ldots \ldots \ldots \ldots$

tomentosum

tom. plicatum

2 to $3 \mathrm{ft} . . . \ldots \ldots \ldots \ldots \ldots \ldots . \ldots \ldots$

3 to $4 \mathrm{ft} . \ldots \ldots \ldots \ldots \ldots \ldots \ldots$

XANTHORRHIZA apiifolia

6 to 12 in.
Each Per 10 Per 100

Maple-leaved Viburnum

$50 \quad 400$

$60 \quad 500$

Withe Rod

$\begin{array}{llll}50 & 400 & 3200\end{array}$

$\begin{array}{lllll}75 & 600 & 4000\end{array}$

Arrowwood

$\begin{array}{lllll}50 & 400 & 30 & 00\end{array}$

$\begin{array}{lllll}60 & 500 & 40 & 00\end{array}$

$\begin{array}{lllll}75 & 600 & 00 & 00\end{array}$

Wayfaring Tree

$\begin{array}{lllll} & 3 & 50 & 24 & 00\end{array}$

Sheep Berry

$400 \quad 3000$

$\begin{array}{lllll}50 & 4 & 50 & 40 & 00\end{array}$

$\begin{array}{lllll}75 & 600 & 50 & 00\end{array}$

$100 \quad 800 \quad 7000$

$\begin{array}{llllll}1 & 50 & 1200 & 9000\end{array}$

High-bush Cranberry

$\begin{array}{lllll}50 & 400 & 30 & 00\end{array}$

$\begin{array}{lllll}60 & 5 & 00 & 40 & 00\end{array}$

$\begin{array}{lllll}75 & 600 & 50 & 00\end{array}$

$100 \quad 800$

Common Snowball

$50 \quad 400$

Single Japanese Snowball $\begin{array}{llll}50 & 400 & 30 & 00\end{array}$

Japanese Snowball

$60 \quad 500$

75

Yellow Root

$250 \quad 1800$ 


\section{VINES AND GLIMBERS}

ACTINIDIA arguta

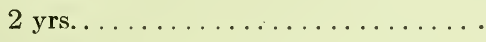

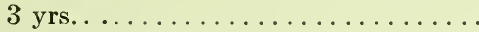

AMPELOPSIS quinquefolia

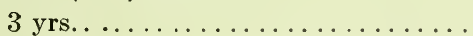

quinq. engelmanni

3 yrs.

veitchii

2 yrs.

ARISTOLOCHIA sipho

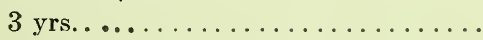

BIGNONIA radicans

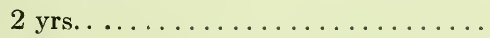

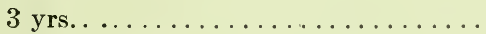

CELASTRUS articulatus

3 yrs......

scandens

3 yrs....................

CLEMATIS coccinea

2 yrs.

paniculata

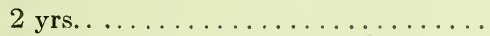

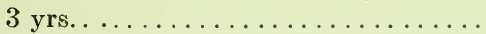

virginiana

2 yrs.
Each Per 10 Per 100 Actinidia

$50 \quad 400 \quad 3000$

$\begin{array}{lllll}75 & 6 & 00 & 50 & 00\end{array}$

Virginia Creeper

$\begin{array}{llll}50 & 360 & 2400\end{array}$

Clinging Virginia Creeper

$\begin{array}{lll}60 & 400 \quad 3000\end{array}$

Boston Ivy

$50 \quad 4 \quad 00$

Dutchman's Pipe

$75 \quad 650$

Trumpet Vine

$\begin{array}{lllll}50 & 400 & 30 & 00\end{array}$

$\begin{array}{lllll}75 & 600 & 50 & 00\end{array}$

Japanese Bittersweet

$50 \quad 400$

Roxbury Waxwork

$50 \quad 400 \quad 3000$

Scarlet Clematis

$\begin{array}{ll}75 & 650\end{array}$

Japanese Clematis

$\begin{array}{lllll}50 & 4 & 00 & 30 & 00\end{array}$

$\begin{array}{lllll}75 & 6 & 00 & 45 & 00\end{array}$

A merican Clematis

$\begin{array}{lllll}50 & 4 & 00 & 30 & 00\end{array}$

\section{LARGE FLOWERING GLEMATIS}

Two-year plants, 75 . each; $\$ 6.00$ per ten.

DUCHESS OF EDINBURG-Double. White. Fragrant.

JACKMAN II-Large. Velvety purple.

MME. BARON VEILLARD-Unique shade of soft pink.

RAMONA-Light blue.

EUONYMUS radicans-See under Evergreen Shrubs

HEDERA helix

from 4 in. pots
English Ivy

$\begin{array}{llll}50 & 400 & 3000\end{array}$ 
LONICERA brachypoda halleana

Hall's Honeysuckle

2 yrs.

$50 \quad 400 \quad 3000$

sempervirens 2 yrs.................. 50

LYCIUM chinensis

Matrimony Vine

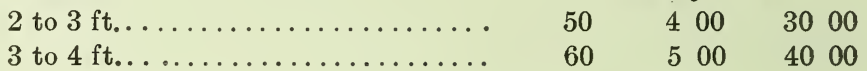

TECOMA-See BIGNONIA

VITIS coignetia

Crimson Glory Vine

2 yrs.................. $50 \quad 400 \quad 3000$

5 yrs.................. $100 \quad 800$

heterophylla

Japanese Grape

3 yrs................... $60 \quad 500$

WISTARIA chinensis

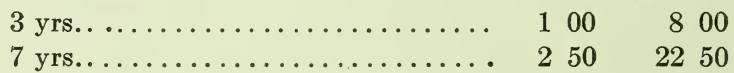

chin. alba

Chinese White Wistaria

3 yrs.................... $100 \quad 800$

10 yrs................... 300 


\section{ROSES}

\section{HARDY JUNE ROSES}

Hybrid Perpetual and Other Varieties

Two-year, field-grown plants, .75 each; $\$ 6.50$ per ten.

If we are out of the variety ordered we shall select the variety most nearly approaching the color of the desired sort UNLESS OTHERWISE SPECIFIED.

AMERICAN BEAUTY-Large. Red.

CRESTED MOSS-Deep pink.

FISHER HOLMES-Large. Brilliant crimson.

FRAU KARL DRUSCHKI-Large. Pure white.

GEN. JAQUEMINOT-Brilliant erimson.

HUGH DICKSON-Brilliant crimson. Fragrant.

LOUIS VAN HOUTTE-Red. Fragrant.

MME. GABRIEL LUIZET - Silvery pink. Fragrant

M. P. WILDER - Large. Carmine. Fragrant.

MRS. JOHN LAING-Soft pink. Large. Fragrant.

PAUL NEYRON-Deep pink. Large. Fragrant.

PERSIAN YELLOW-Small. Bright Yellow.

PRINCE CAMILLE DE ROHAN-Dark Red.

SOLEIL D'OR-Yollow.

ULRICH BRUNNER-Brilliant cherry red.

\section{EVER BLOOMING ROSES}

Two-year, field-grown plants, 1.00 each; $\$ 8.50$ per ten.

If we are out of the variety ordered we shall select the variety most nearly approaching the color of the desired sort UNLESS OTHERWISE SPECIFIED.

BABY DOROTHY PERKINS-Pink.

BABY RAMBLER-Red.

CATHERINE ZEIMET - White Brby R:mbler.

GEN. MACARTHUR-Large. Sweet. Crimson-scarlet.

GRUS AN TEPLITZ-Double. Deep red. Fragrant.

JESSE-Bright cherry-red. Baby rambler.

JUBILEE-Large. Velvety crimson. Fragrant.

KAISERIN AUGUSTA VICTORIA-Cream white. Fragrant.

KILLARNEY - Deep shell-pink.

KILLARNEY WHITE-Pure white; long pointed buds.

LA FRANCE-Silvery pink. Fragrant.

MME. CAROLINE TESTOUT-Large. Double. Piik

MME. JULES GROLEZ-Pink. Fragrant

MME. LEON PAINE-Silvery salmon; orange yellow center.

MRS. AARON WARD-Coppery orange in bud; pinkish fawn when open. SUNBURST-Brilliant yellow orange. 


\section{HARDY RAMBLERS}

Two-year, field-grown plants, .75 each; $\$ 6.50$ per ten.

CRIMSON RAMBLER

WHITE RAMBLER

PINK RAMBLER

YELLOW RAMBLER

\section{CLIMBING AND TRAILING ROSES}

Two-year, field-grown plants, .75 each; $\$ 6.50$ per ten.

AMERICAN BEAUTY, CLIMBING-Rose pink.

AMERICAN PILLAR-Large. Single. Pink.

DAWSON-Bright pink. Semi-double. Fragrant.

DOROTHY PERKINS-Double. Pink.

DR. VAN FLEET-Flesh pink.

EXCELSA-Double. Red.

HIAWATHA —Single. Crimson; yellow center.

LADY GAY - Cherry pink.

QUEEN OF THE PRAIRIE-Double. Red.

SILVER MOON-Silvery pink; yellow stamens.

TAUSENDSCHON - Large. Pink and white. Fragrant.

\section{ROSA RUGOSA HYBRIDS}

Two year, field grown plants, 1.00 each; $\$ 8.50$ per ten.

CONRADI FERD. MEYER-Silvery rose. Large. Double. Fragrant. MME. GEORGE BRUANT-Semi-double. Pure white.

ROSERAIE DE L'HAY-Crimson. 


\section{FRUIT TREES}

\section{APPLES}

Each Per 10 Per 100

$$
5 \text { to } 7 \mathrm{ft} ., 11-16 \text { in. and up ...... } 100 \quad 900
$$

\section{Summer Varieties}

Astrachan, Sweet Bough, Williams, Yellow Transparent

\section{Autumn Varieties}

Fameuse, Gravenstein

\section{Winter Varieties}

Baldwin, Northern Spy, Porter, Rhode Island Greening, Roxbury Russett, Talman Sweet, Wealthy, Wolfe River"

Delicious, McIntosh............... $125 \quad 1000$

\section{DWARF APPLES}

3 to $5 \mathrm{ft} ., 1 / 2$ in. caliper......... $100 \quad 900$

\section{Summer Varieties}

$\checkmark$ Astrachan, Early Harvest, Williams, Yellow Transparent

\section{Autumn Varieties}

Gravenstein

\section{Winter Varieties}

Baldwin, Rhode Island Greening, Wealthy

\section{CRAB APPLES}

5 to $7 \mathrm{ft} ., 11-16$ in. and up ...... $100 \quad 900$

Hyslop, Martha, Transcendent

\section{CHERRIES}

5 to $7 \mathrm{ft} ., 11-16$ in. and up........ $125 \quad 1000$

Black Tartarian, Early Richmond, Gov. Wood, Montmorency,

Napoleon, Windsor, Yellow Spanish

\section{PEACHES}

4 to $6 \mathrm{ft} ., 1 / 2$ in. and up........ $100 \quad 900$

Carman, Champion, Crawford Early, Crawford Late, Elberta,

Fitzgerald, Greensboro, Mt. Rose, Old Mixon 
PEARS, STANDARD

\section{Each Per 10 Per 100}

5 to $7 \mathrm{ft.}, 11-16$ in. and up ....... $100 \quad 900$

Anjou, Bartlett, Clapp's, Duchess, Flemish Beauty, Lawrence, Seckel, Sheldon

\section{DWARF PEARS}

3 to $5 \mathrm{ft} ., 1 / 2$ in. and up.......... $100 \quad 900$

Anjou, Bartlett, Clapp's, Duchess, Seckel

\section{PLUMS}

5 to $7 \mathrm{ft} ., 11-16$ in. and up....... $125 \quad 1000$

Abundance, Bradshaw, Burbank, Lombard, Reine Claude, Satsuma, Shropshire, Damson, Wickson, Yellow Fgg

\section{QUINCES}

$5 / 8$ in. cal. ................ $100 \quad 850$

Orange

\section{SMALL FRUITS}

\section{GRAPES}

Brilliant-red

1 yr. ................... $60 \quad 500$

Concord-blue

Green Mountain-white

Ioore's Early-blue

$$
2 \text { yrs................... } 80 \quad 700
$$

Brighton-red

Campbell's Early-black

Concord-blue

RASPBERRIES

120

800

Cuthbert, Cumberland, Columbian, Golden Queen, St. Regis

BLACKBERRIES

120

800

Eldorado, Rathbun

\section{ASPARAGUS}

Giant Argenteuil ...................

\section{RHUBARB}

Linneas 


\section{INDEX TO BOTANICAL NAMES}

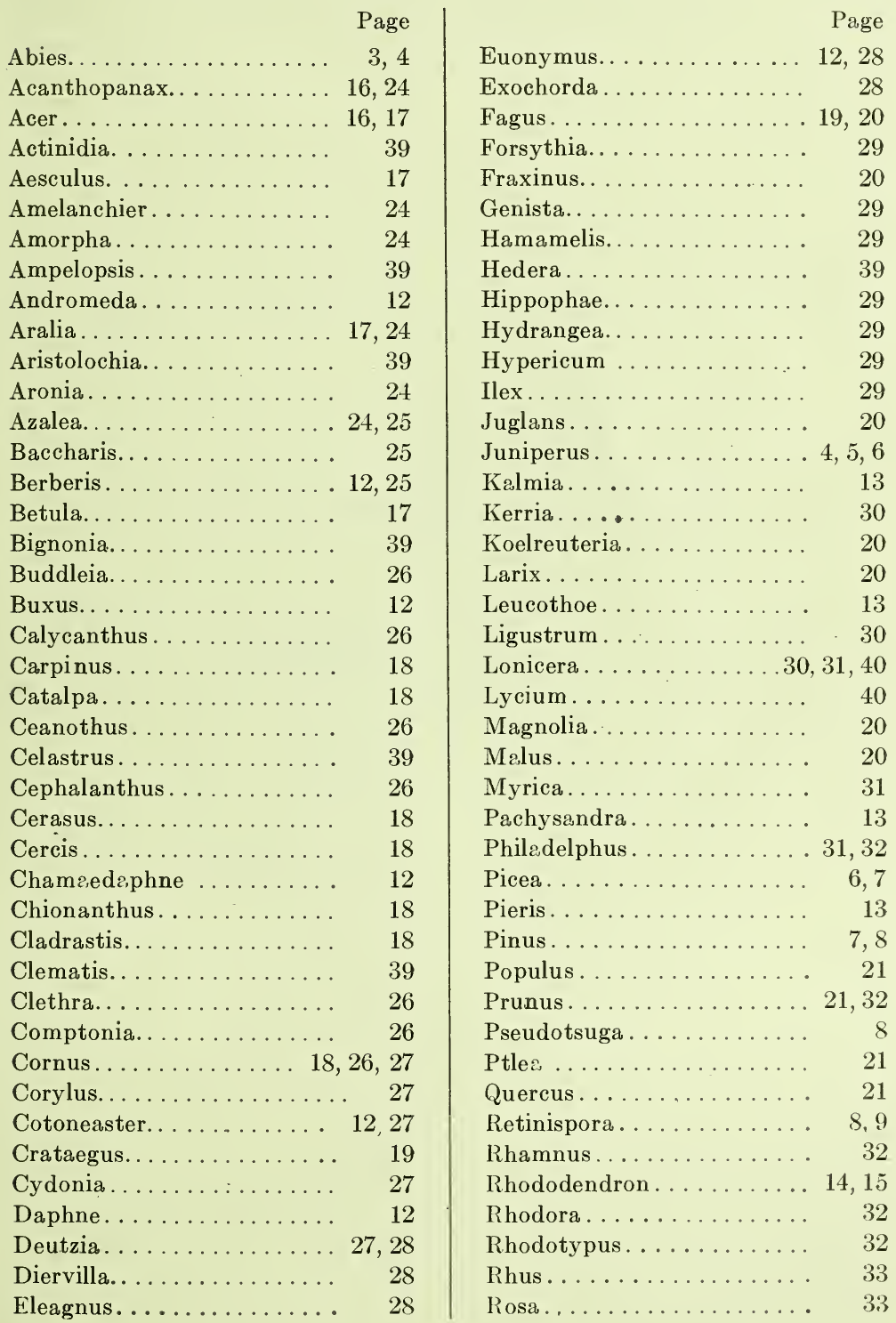




\begin{tabular}{|c|c|c|}
\hline Page & & Page \\
\hline Roses............441, 42 & Taxodium ........... & 2 \\
\hline Rubus.............. & Taxus $\ldots \ldots \ldots \ldots \ldots$ & 9,1 \\
\hline Salix............. & Tecoma............. & \\
\hline Sambucus............. & Thuya............... & 10,1 \\
\hline Sassafras. . . . . . . . . & Tilia............... & \\
\hline Sciadopitys............ & Tsuga............... & \\
\hline Sophora.............. & Ulmus. . . . . . . . . . . . & \\
\hline Sorbaria............. & Vaccinium ........... & \\
\hline Sorbus.............. & Viburnum............ & \\
\hline Spiraea............. 34, 35 & Vinca............... & \\
\hline Stephanandra.......... & Vitis . . . . . . . . . . & \\
\hline Symphoricarpos......... & Wistaria............ & \\
\hline Syringa....... 22, 35, 36, 37 & Xanthorrhiza.......... & \\
\hline Tamarix............. & & \\
\hline
\end{tabular}

\section{INDEX TO COMMON NAMES}

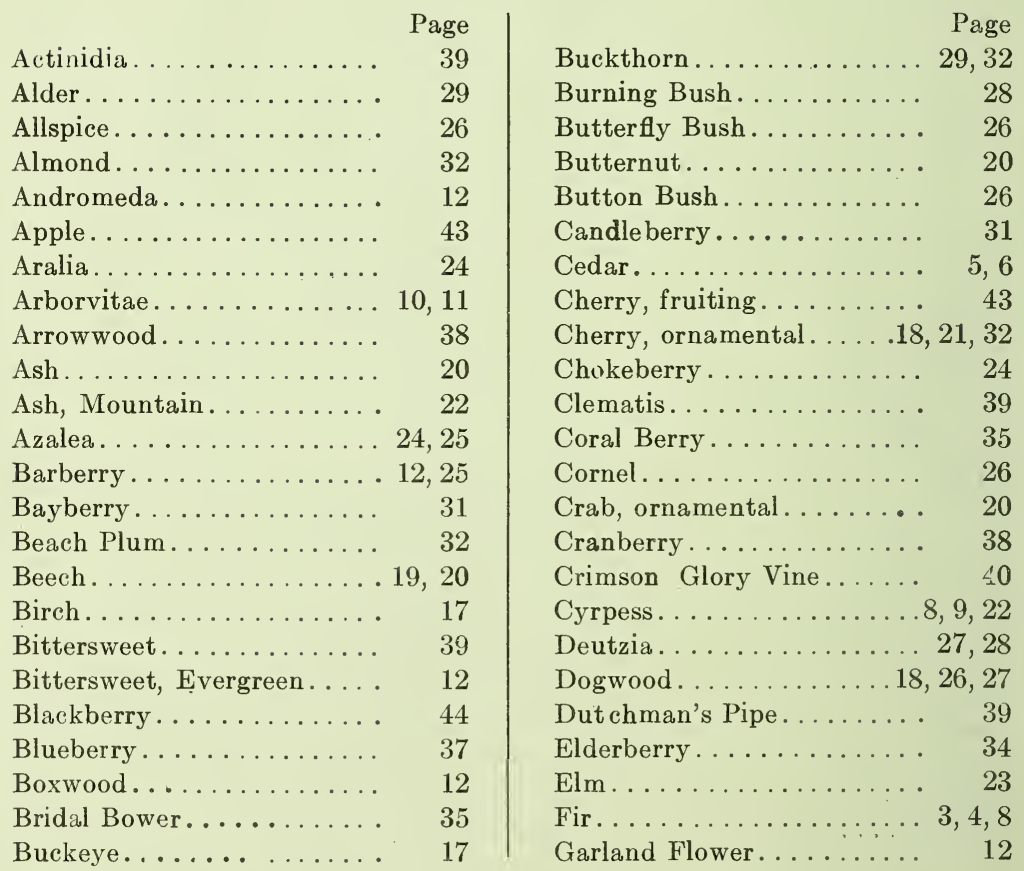


Page

Golden Bell........... 29

Grape, ornamental ...... 40

Grapes.............. 44

Greenweed............ 29

Groundsel Bush......... 25

Hardhack ............ 35

Hawthorn ............ 19

Hemlock............ 11

Hercules Club. . . . . . . . 17

Honeysuckle . . . . . .25, 30, 31, 40

Hop Tree ........... 21

Hornbeam........... 18

Horse Chestnut. . . . . . . 17

Hydrangea. . . . . . . . . 29

Indian Bean. . . . . . . . 18

Ivy . . . . . . . . . . 12, 39

Juniper . . . . . . . . 4, 5, 6

Kerria.............. 32

Lace Shrub. . . . . . . . . $\quad 35$

Larch.............. 20

Laurel. . . . . . . . . . . . 13

Lead Plant............. 24

Leather Leaf . . . . . . . . . 12

Lilac . . . . . . . . 22, 35, 36, 37

Lily-of-the-Valley Shrub . . . 13

Linden............... 23

Magnolia............. 20

Maple............. 16, 17

Mstrimony Vine........ 40

Mock Orange......... . 31, 32

Mountan Ash.......... 22

Myrtle............. 13

Nine Bark............ 34

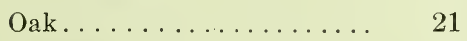

Oleaster.............. 28

Osier................ 26

Pägoda Tree........... 22

Peaches.............. 44

Pearl Bush............ 28

Pears................ 44

Pine........... 7, 8, 9

Pinxter Flower......... 25

Plum, Beach.......... 32

Plum, Fruiting. ........ 44

Plum, Ornamental....... 21

Poplar............... 21

Privet.............. 30

Quince, Ornamental...... 27

Raspberry, Flowering. . . . . 34

Raspberry, Fruiting ...... 44

Red Bud.............. 18

Rhododendron......... 14, 15

Rhodora............. 24

Rose............ . 33, 41, 42

Rose Box........... 12, 27

Roxbury Waxwork....... 39

Saint John's Wort. . . . . . 29

Sassafras. . . . . . . . . . 22

Shad Bush........... 24

Sheep Berry........... 38

Smoke Bush........... 33

Snowball............. 38

Snowberry .................... 35

Snow Garland. . . . . . . . 34

Spindle Tree........... 28

Spiraea............ 34, 35

Spruce........... 6,7

Spurge............. 13

Sumac............. 33

Sweet Fern. ........... 26

Sweet Pepper Bush...... 26

Syringa............ 31

Tamarisk............ 37

Tea, New Jersey . . . . . . . . 26

Thorn.............. 19

Thorny Club .......... 16

Trumpet Vine. . . . . . . . . 39

Varnish Tree........... 20

Viburnum............. 38

Virginia Creeper........ 39

Wayfaring Tree......... 38

Weigela............. 28

White Fringe.......... 18

Willow............. 22

Winterberry . . . . . . . . . 29

Witch Hazel. . . . . . . . . 29

Withe Rod............ 38

Wistaria............ 40

Yellow Root........... 38

Yellow Wood............ 18

Yew............. 9, 10 


\section{OUR LOGATION}

FRAMINGHAM NURSERIES are located in Framingham, Mass., about 20 miles from Boston and from Worcester, on the main line of the Boston \& Albany division of the New York Central R.R. Also on the New Haven R.R.

Nearly all of the trains to Boston from the West and from New York by the way of Springfield stop here. Trains leave the South Station, Boston, for Framingham every fifteen or twenty minutes.

We are situated about two miles from the Framingham station. We are reached from that point by the Boston-bound cars of the Boston \& Worcester Street Railway Co. Ask the conductor for the FRAMINGHAM NURSERIES STOP. Phone us from the Framingham station and we will meet you there.

From Boston we may also be reached by any local car of the Boston \& Worcester Street Railway Co. which goes as far as Framingham Junction. These cars leave from Park Square. Ask the conductor for our stop. From Worcester, any Boston-bound local car will leave you at our stop.

By motor from the West, turn from the New York \& Boston Motor Road to the right at East Sudbury and continue for about three miles. From Boston take Commonwealth Ave. to its end, then South St. for about seven miles. You can't help seeing our swinging sign.

Visitors are cordially invited to inspect our nurseries on week days. We are POSITIVELY CLOSED TO BUSINESS ON SUNDAY. 